OAK RIDGE NATIONAL LABORATORY

\section{MARTIN MARUETIA}

\title{
Utility DSM Programs from 1989 Through 1998: Continuation or Cross Roads?
}

\author{
Stan Hadley
}

Eric Hirst

\section{MANAGED BY}

MARTIN MARIETTA ENERGY SYSTEMS, INC.

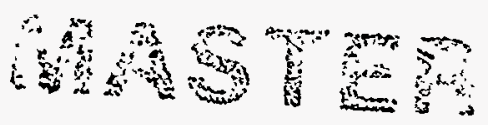

FOR THE UNITED STATES

DEPARTMENT OF ENERGY 
This report has been reproduced directly from the best available copy.

Available to DOE and DOE contractors from the Office of Scientific and Technical Information, P.O. Box 62, Oak Ridge, TN 37831; prices available from (615) 576-8401, FTS 626-8401.

Available to the public from the National Technical Information Service, U.S. Department of Commerce, 5285 Port Royal Rd., Springfield, VA 22161.

This report was prepared as an account of work sponsored by an agency of the United States Government. Neither the United States Government nor any agency thereof, nor any of their employees, makes any warranty, express or implied, or assumes any legal liability or responsibility for the accuracy, completeness, or usefulness of any information, apparatus, product, or process disclosed, or represents that its use would not infringe privately owned rights. Reference herein to any specific commercial product, process, or service by trade name, trademark, manufacturer, or otherwise, does not necessarily constitute or imply its endorsement, recommendation, or favoring by the United States Government or any agency thereof. The views and opinions of authors expressed herein do not necessarily state or reflect those of the United States Government or any agency thereof. 


\title{
UTILITY DSM PROGRAMS FROM 1989 THROUGH 1998: CONTINUATION OR CROSS ROADS?
}

\author{
STAN HADLEY and ERIC HIRST
}

February 1995

\begin{abstract}
Sponsored by
Office of Energy Efficiency and Renewable Energy

U.S. Department of Energy
\end{abstract}

OAK RIDGE NATIONAL LABORATORY

Oak Ridge, Tennessee 37831 managed by

MARTIN MARIETTA ENERGY SYSTEMS, INC.

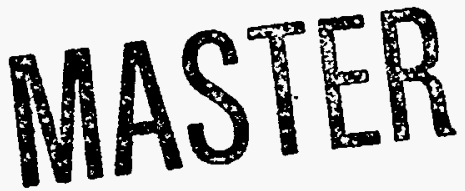
for

U.S. DEPARTMENT OF ENERGY under contract No. DE-AC05-84OR21400 


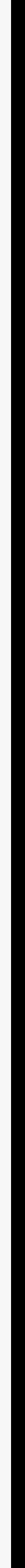




\section{DISCLAIMER}

Portions of this document may be illegible in electronic image products. Images are produced from the best available original document. 
LIST OF TABLES vii ACRONYMS viii

SUMMARY ix

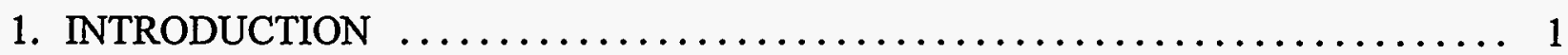

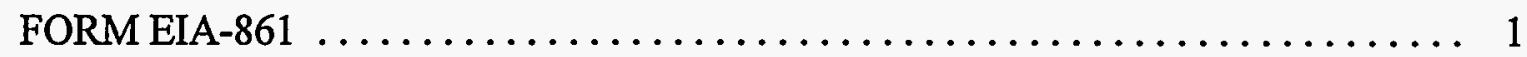

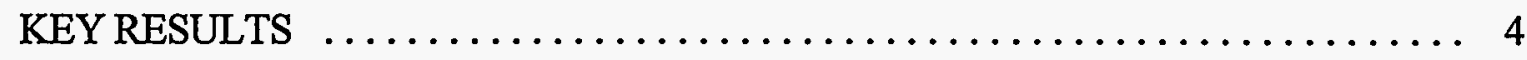

2. 1993 DSM-PROGRAM EXPENDITURES $\ldots \ldots \ldots \ldots \ldots \ldots \ldots \ldots \ldots \ldots$

3. 1993 DSM-PROGRAM ENERGY SAVINGS $\ldots \ldots \ldots \ldots \ldots \ldots \ldots \ldots \ldots \ldots \ldots$

4. 1993 DSM-PROGRAM DEMAND REDUCTIONS $\ldots \ldots \ldots \ldots \ldots \ldots \ldots \ldots \ldots . \ldots \ldots$

5. UTILITY TRENDS AND FORECASTS TO $1998 \ldots \ldots \ldots \ldots \ldots \ldots \ldots \ldots \ldots \ldots \ldots$

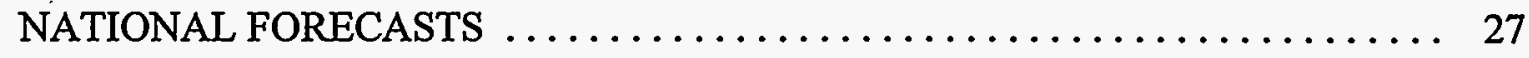

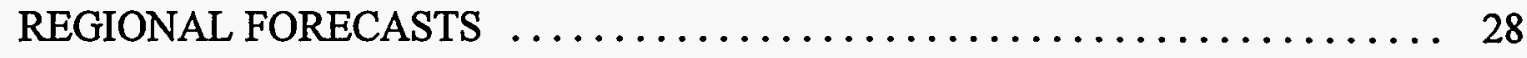

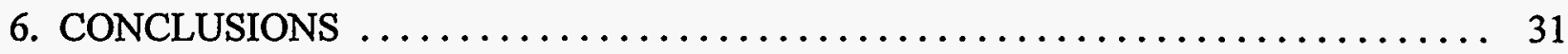

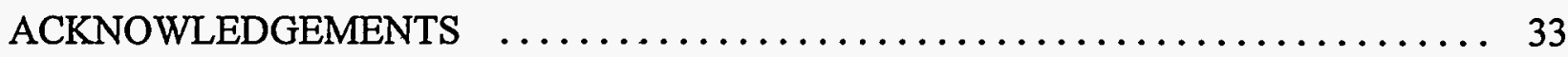

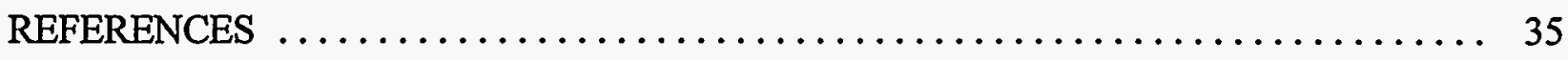





\section{LIST OF FIGURES}

S-1. Actual and projected DSM expenditures, annual energy savings, and potential

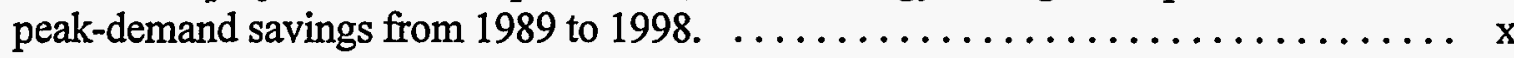

S-2. Percentage of retail revenues spent on DSM programs by state in $1993 . \ldots \ldots \ldots$.

1. Costs and effects of electric-utility DSM programs for 1989 to 1993 and

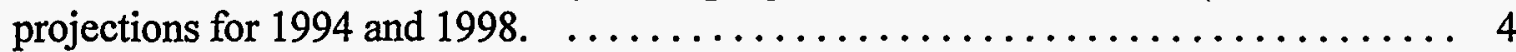

2. 1992 and 1993 projections of DSM expenditures, annual energy savings, and peak

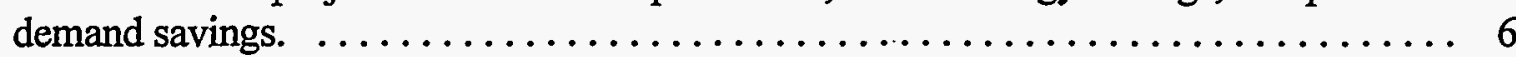

3. 1993 DSM program expenditures and effects by program types. . . . . . . . . 7

4. Distribution of utilities with sales over $120 \mathrm{GWh}$ that have DSM programs by percentage of total revenues spent on DSM. . . . . . . . . . . . . . . . . 12

5. Changes in DSM spending for the 25 highest-spending utilities in $1993 . \ldots \ldots \ldots 13$

6. Percentage of retail revenue spent on DSM programs by state in $1993 . \ldots \ldots \ldots 14$

7. Percentage change in DSM expenditures between 1992 and 1993. .......... 14

8. Shares of 1993 annual energy savings (effects of all DSM programs), incremental energy savings (effects of 1993 programs), and energy sales by customer class. . . . 16

9. Distribution of the utilities with sales over $120 \mathrm{GWh}$ that have DSM programs by percentage of energy saved by those programs.

10. Percentage reduction in retail sales caused by utility DSM programs by state for 1993.

11. Shares of 1993 annual peak reductions (effects of all DSM programs) and incremental peak savings (effects of 1993 DSM programs) by customer class. .....

12. Distribution of the utilities with sales over $120 \mathrm{GWh}$ that have DSM programs by percentage of potential peak demand saved.

13. Percentage reduction in potential peak demand caused by utility DSM programs by state for 1993. 
14. North American Electric Reliability Council regions for the contiguous U.S. . . . . . 28

15. DSM expenditures as a percentage of retail revenue for each NERC region for 1992, 1993, and projected 1994 and 1998.

16. Energy savings as a percentage of total sales for each NERC region for 1992, 1993, and projected 1994 and 1998.

17. Potential peak demand reduction as a percentage of total peak for each NERC region for 1992, 1993, and projected 1994 and 1998. 
1. Key elements of DSM data required by EIA-861 for $1993 \ldots \ldots \ldots \ldots \ldots \ldots$

2. Annual costs and effects of electric-utility DSM programs, 1989 to 1998 ....... 5

3. The 25 utilities with the largest 1993 DSM expenditures $\ldots \ldots \ldots \ldots \ldots \ldots \ldots$

4. The 25 utilities with the largest 1993 DSM expenditures as a percentage of revenue $\ldots \ldots \ldots \ldots \ldots \ldots \ldots \ldots \ldots \ldots \ldots \ldots \ldots \ldots \ldots \ldots \ldots \ldots \ldots \ldots \ldots \ldots, 11$

5. The 25 utilities with the largest 1993 annual energy savings caused by DSM $\ldots \ldots 18$

6. The 25 utilities with the largest 1993 annual demand savings caused by DSM $\ldots . .24$ 


\section{ACRONYMS}

BPA Bonneville Power Administration

COU Consumer-owned utility

DSM Demand-side management

EEI Edison Electric Institute

EIA Energy Information Administration

GW Gigawatt

GWh Gigawatt-hour

IOU Investor-owned utility

$\mathrm{kW} \quad$ kilowatt

$\mathrm{kWh} \quad$ kilowatt-hour

MW megawatt

NERC North American Electric Reliability Council

ORNL Oak Ridge National Laboratory

RIM Rate Impact Measure

TRC Total Resource Cost 


\section{SUMMARY}

Over the past five years, the Energy Information Administration (EIA) has been collecting data annually from U.S. electric utilities on their demand-side management (DSM) programs, both current and projected. The latest data cover activities for 1993 and projections for 1994 and 1998.

In 1993, 991 utilities operated DSM programs. That year, they spent $\$ 2.8$ billion, a $13 \%$ increase over 1992 expenditures. These and earlier DSM programs saved 44,000 GWh of energy and reduced potential peak demand by 40,000 MW, 30\% and 22\% increases over the 1992 values, respectively.

While some people predict the demise of electric-utility DSM programs, the data do not paint so bleak a picture. In most parts of the country, DSM programs grew in 1993 and utilities (as of Spring 1994) projected continued growth through 1998 (Fig. S-1). Expenditures grew from $1.3 \%$ of revenues in 1992 to $1.5 \%$ in 1993 , and are expected to grow $2.5 \%$ per year faster than inflation, which is equivalent to revenue growth. Thus, DSM spending is expected to stay constant at $1.5 \%$ of revenues through 1998. Because of the cumulative effect of DSM programs, energy savings are expected to grow from $1.2 \%$ of sales in 1992 to $1.6 \%$ in 1993 and $3.0 \%$ in 1998. Potential-peak reductions are expected to increase from $5.9 \%$ of peak demand in 1992 to $6.8 \%$ in 1993 and $8.9 \%$ in 1998.

However, the growth in spending is not as rapid as the $8 \%$ annual real growth projected a year earlier. Actual expenditures in 1993 were $6.5 \%$ lower than projected early that year. Energy savings, on the other hand, were the same as projected earlier. Potential peak reductions were actually $9 \%$ higher than previously projected.

Most DSM expenditures (70\%) went toward energy-efficiency programs, which also contributed the most $(90 \%)$ to energy savings. Almost half of the potential peak-demand reductions were provided by interruptible loads. This capacity cost between $\$ 14$ and $\$ 38$ per $\mathrm{kW}$-year, which is economically attractive for utilities. Direct load control, the other major loadmanagement program, cost utilities about $\$ 39 / \mathrm{kW}$-year, which is also competitive with supply resources. The utilities continued to shift their energy-efficiency programs toward the commercial sector and away from the residential sector. Peak-reduction programs concentrated on the industrial sector.

DSM expenditures remained highest in the Northwest and Northeast, but other states also increased their spending. In 1993, utilities in 13 states spent more than $2 \%$ of revenues on DSM, and another 16 spent between 1 and 2\% (Fig. S-2). Spending increased most significantly in the Rocky Mountain, mid-Atlantic, and Southeast states. DSM expenditures were well below average in parts of the Midwest and Southwest. Peak reductions were highest in the Southeast. The only region to show a consistent projected decline in DSM spending was the Northeast. All others either showed continued growth or a mixture of increases and decreases between 1992 and 1993 or 1993 and 1994. Energy savings increased in all regions, with the West displacing the 
Northeast as the region with the highest percentage of savings. Peak reductions were highest in the Southeast and Mid-Continent regions.

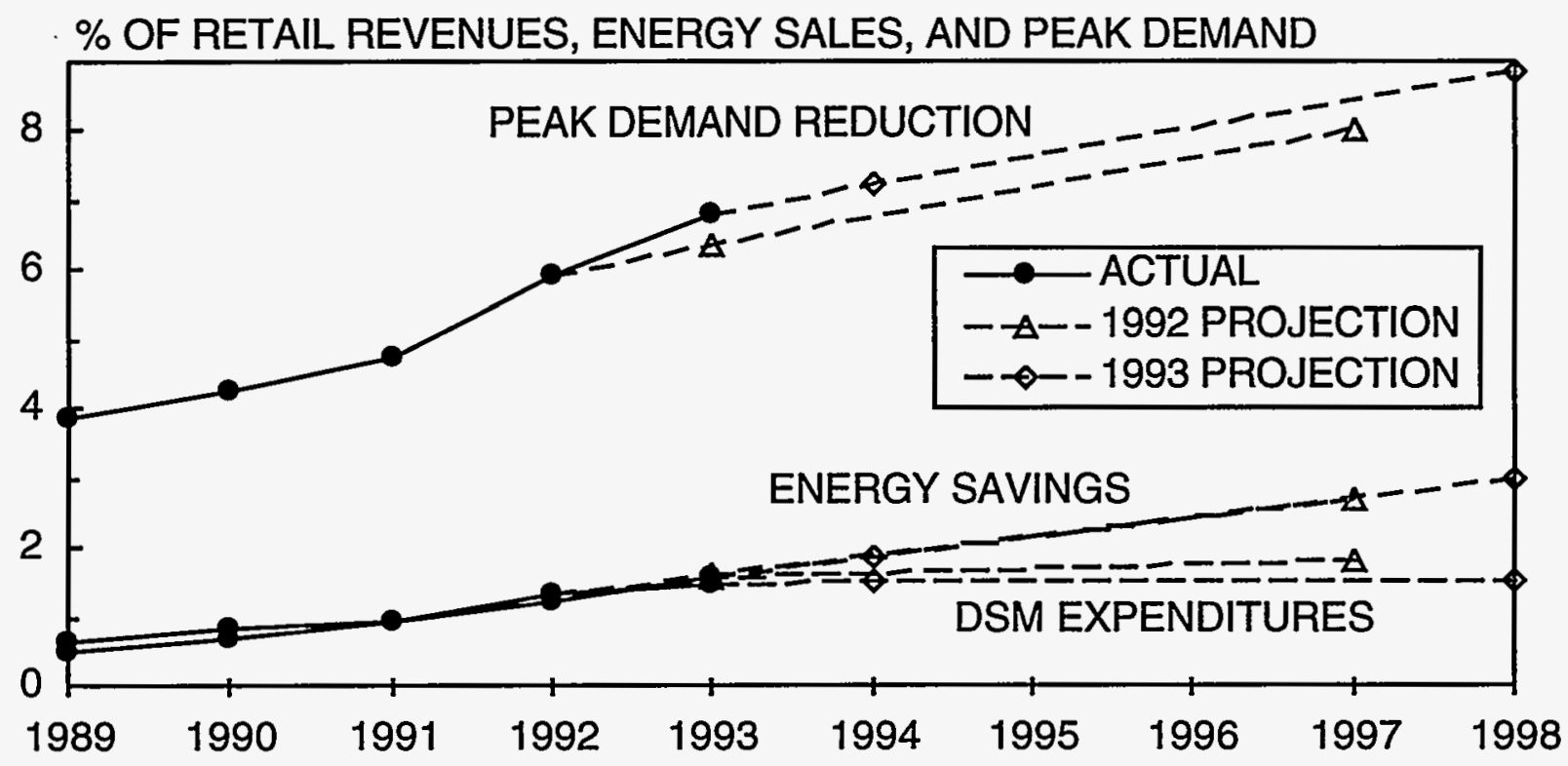

Fig. S-1. Actual and projected DSM expenditures, annual energy savings, and potential peak-demand savings from 1989 to 1998.

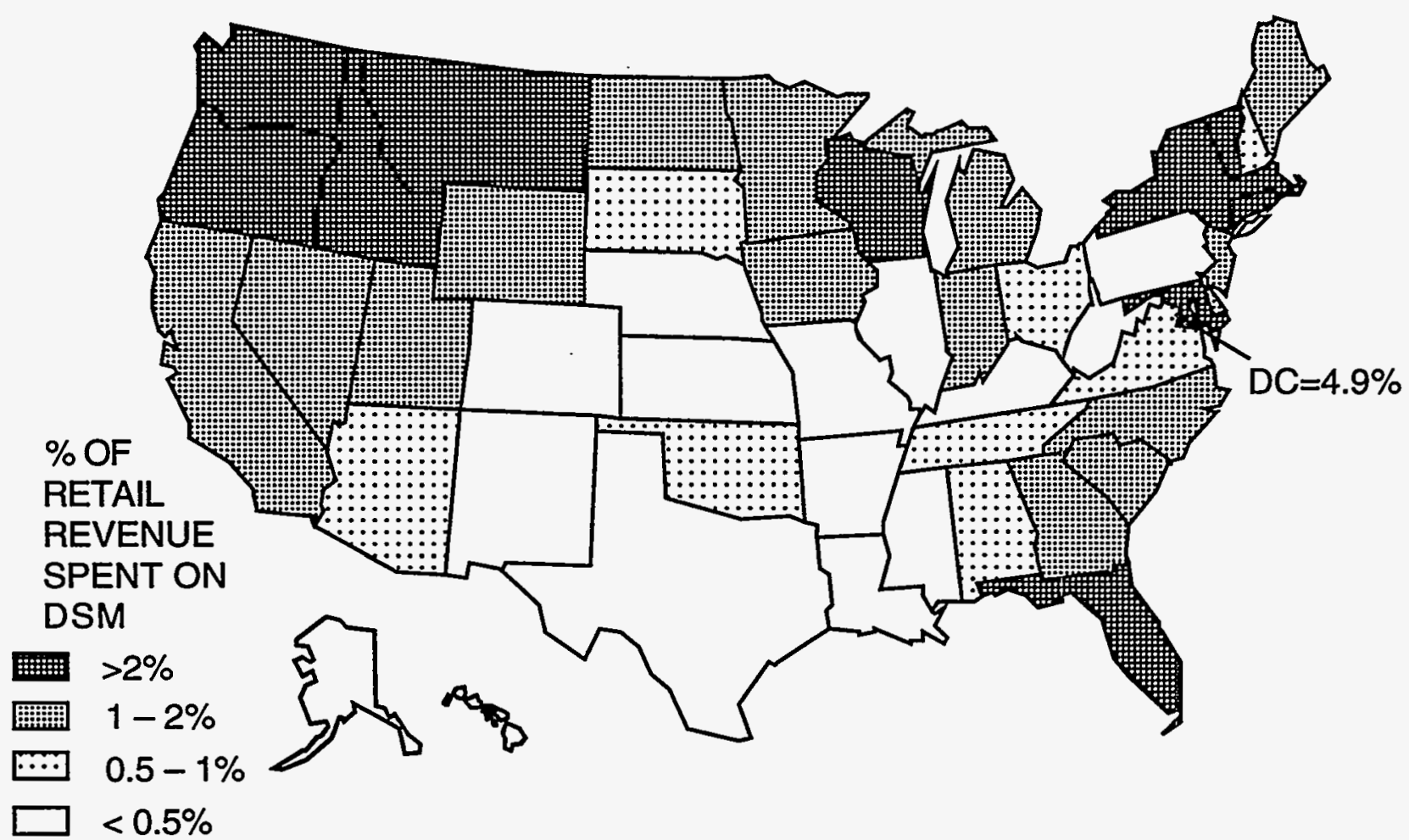

Fig. S-2. Percentage of retail revenues spent on DSM programs by state in 1993. 
Over the past year or two, there has been extensive discussion on restructuring of the electricity industry to increase competition. Many people are concerned that restructuring could affect utility demand-side management (DSM) programs. However, to date at least, utilities continue to pursue DSM as a means to reduce energy and capacity demands on their systems. In 1993, more utilities had active programs and most programs continued to grow relative to prior years. On the other hand, some of the most active DSM utilities began to reduce their programs. Overall, DSM implementation continued to grow, but at a slower pace than earlier predicted.

Since 1989, the Energy Information Administration (EIA), through its form EIA-861, has required all U.S. electric utilities to report annually on their DSM programs. For the years 1989, 1990, and 1991, Schedule V of EIA-861 required all utilities that ran DSM programs and had sales greater than $120 \mathrm{GWh} /$ year to provide information on the costs, energy savings, and load reductions of their DSM programs. Beginning with the 1992 form, EIA expanded the scope of DSM information collected to include disaggregations by program type and customer class. Utilities smaller than $120 \mathrm{GWh}$ in sales also had to submit a subset of the Schedule V information. The most recent EIA report, Electric Power Annual 1993, includes these data (EIA 1994a).*

This report presents data reported to EIA for 1993 as well as utility projections of DSM activities for 1994 and 1998. Also, results from previous Oak Ridge National Laboratory (ORNL) reports on earlier EIA-861 data (Hirst 1992, 1993, and 1994) are used to identify trends. We present results for the "leading" DSM utilities, states, nine North American Electric Reliability Council (NERC) regions, and the U.S. as a whole. Subsequent chapters discuss 1993 DSM-program costs, energy savings, and load reductions; projections for 1994 and 1998; and trends based on data and projections.

\section{FORM EIA-861}

Of the roughly 3400 U.S. electric utilities, 991 reported to EIA that they operated a DSM program in 1993. Of these 991 utilities, 574 had annual sales greater than $120 \mathrm{GWh}$ and were required to complete all of Schedule $\mathrm{V}$. The remaining 417 utilities had to complete only parts of Schedule V. These 991 utilities accounted for $86 \%$ of the electricity sold to U.S. retail customers in 1993 and for $88 \%$ of the revenues collected from those customers that year. Thus, the vast majority of electricity customers are served by utilities that offer DSM programs. Of the 991 DSM utilities, 148 are investor-owned utilities (IOUs), accounting for a little under half of the

* The EIA-861 data from 1991, 1992, and 1993 are available on the Internet in compressed format through FTP at ftp.fedworld.gov or through use of a world-wide-web browser such as Mosaic at www.fedworld.gov in the /pub/energy subdirectory. 
311 such utilities. The remaining 843 DSM utilities are consumer-owned utilities (COUs), including municipal, cooperative, federal, and state utilities. These COUs account for about onefourth of the 3100 consumer-owned utilities.

Schedule V of EIA-861 includes several questions about the costs and effects of utility DSM programs at an aggregate level plus questions on incremental and annual electricity savings and demand reductions (Table 1). These energy and load effects were disaggregated by customer class (i.e., residential, commercial, industrial, and other) and by program type (i.e., energy efficiency, direct load control, interruptible load, other load management, other DSM, and load building). Cost data were split into direct and indirect utility costs. Direct costs were disaggregated by program type, and indirect costs were split into administrative, marketing, monitoring and evaluation, utility-earned incentive, and other costs. In addition to requesting data on utility costs, EIA-861 requested data on nonutility (e.g., customer) costs of DSM programs. EIA requested these data for 1993 plus projections for 1994 and 1998.

In this report, we exclude the costs and effects of load-building programs, both because they do not contribute to energy savings and because they account for small shares of the totals. (Utilities reported directly spending only \$31 million on these programs in 1993 in exchange for increased sales of $3,400 \mathrm{GWh}$ and higher peak demands of almost $500 \mathrm{MW}$. These numbers are around $1 \%$ of total DSM expenditures and demand reductions and $8 \%$ of energy savings.) We discuss potential, rather than actual, peak-demand reduction because it provides a view of DSM more consistent with utility treatment of supply resources. For example, when reporting capability, utilities provide information on all generating units that were available to meet demand at the time of system peak, regardless of whether those units actually operated or not. To be consistent, the DSM resource should identify all the demand reductions available to the utility, even if some of the direct-load-control or interruptible options were not exercised. We use the actual peak reduction from energy-efficiency programs in our figures for potential peak reduction because their potential equals what they actually save.

The EIA-861 data provide a valuable source of information on U.S. utility DSM efforts and accomplishments, especially with the additional detail collected in 1992 and 1993. However, as with any large data set for which information is provided by a diversity of organizations, there are bound to be data-quality problems. As discussed in Hirst and Sabo (1991), Eto et al. (1994), and the earlier versions of this report (Hirst 1992, 1993, and 1994), readers should view the numbers reported here with some skepticism. For example, upon calculating the levelized cost of incremental energy saved we found that 35 utilities had costs over $10 \phi / \mathrm{kWh}$ and nine of them had costs over $\$ 1.00 / \mathrm{kWh}$. Some of these high values may reflect utility concentration on peak reductions that have little energy savings or delays in when program-induced savings will appear, but others may be data errors. For example, many utilities showed incremental energy savings for 1993 significantly lower than the increase between 1992 and 1993 annual values.

Although the utilities with sales of less than $120 \mathrm{GWh}$ were not required to report annual figures, we do not separate them in our national and regional totals. These small utilities account 
for less than $1 \%$ of most DSM totals. However, when counting the number of utilities at different levels of DSM activity (e.g, Figs. 4, 9, and 12) we use only those above $120 \mathrm{GWh}$. This is because we categorized utilities based on annual savings, which the smaller utilities did not have to report.

Table 1. Key elements of DSM data required by EIA-861 for 1993

\section{Program Effects}

Incremental - changes in 1993 energy use and peak load caused by new participants (i.e., those that began participation in 1993) in the utility's DSM programs; these estimates assume that all these customers began participation on January 1, 1993 so the values reported can be higher than actual amounts

Annual - changes in 1993 energy use and peak load caused by all the participants in the utility's DSM programs, including those that participated in 1993 as well as those that participated earlier

\section{Peak Reduction}

Potential — the "installed" reduction in 1993 peak load that could have been achieved by customers participating in the utility's DSM programs, which is larger than the actual peak reduction because of direct-load-control or interruptible options not exercised by the utility in 1993a

Actual - the actual reduction in 1993 peak load achieved by customers participating in the utility's DSM programs

\section{Program Type}

Energy efficiency — programs aimed at reducing electricity use, typically without reducing the services provided, generally without regard for the timing of program-induced savings

Direct load control - programs that can interrupt customer loads at critical times, under the direct control of the utility system operator

Interruptible load - programs with contractual arrangements that permit the utility system operator to request customer load reductions at critical times

Other load management - programs other than direct load control and interruptible load that limit or shift usage from on-peak to off-peak periods, such as energy storage and aggressive promotion of time-of-use pricing

Other DSM - a residual category to include programs that cannot be meaningfully included in any of the other categories, including fuel switching and self-generation

Load building - programs aimed at increasing electricity use

\section{Program Costs}

Direct - those costs that can be directly attributable to a particular DSM program

Indirect - those costs that cannot be meaningfully attributed to a particular program, including administrative, marketing, monitoring and evaluation, and utility incentive costs

aEIA's aggregation of programs for potential peak reductions excludes the actual reductions caused by energy-efficiency programs.

Source: EIA instructions for Schedule V of EIA-861. 
In general, the expenditure data are more reliable than are the energy and demand estimates. The cost figures are typically actual expenditures in various utility accounts, whereas the energy-saving and demand-reduction figures are estimates. Annual energy and peak savings (the savings in a particular year from all past and current DSM programs) appear more consistent than the incremental numbers (the annualized savings from DSM programs that were run in a particular year.) Therefore, we conducted most of our analysis using annual rather than incremental values. As one aggregates from utilities to states to regions to the nation, the accuracy of the results improves. The overall quality of utility DSM-program data has greatly improved over previous years, likely due to increased standardization of terms, more utility experience with DSM, and strong efforts at corroboration by EIA and its subcontractor.

\section{KEY RESULTS}

Utilities continued to increase their spending on DSM in 1993, raising the amount spent from $\$ 2.6$ billion in 1992 to $\$ 2.8$ billion in 1993 (Fig. 1 and Table 2.) Projections for 1994 and 1998 , made in Spring 1994, show continued increases as well, to $\$ 3.0$ and $\$ 3.2$ billion, respectively. (All amounts are in 1993 dollars.) The 1993 value represents $1.5 \%$ of retail revenues for all utilities. Energy savings and peak reduction also grew in 1993. Total energy saved in 1993 from all DSM programs, including previous years' efforts, was over 44,300 $\mathrm{GWh}$, which represents $1.6 \%$ of total retail sales. Peak demand in 1993 was reduced $6.8 \%$, or $39,600 \mathrm{MW}$, because of DSM programs.*

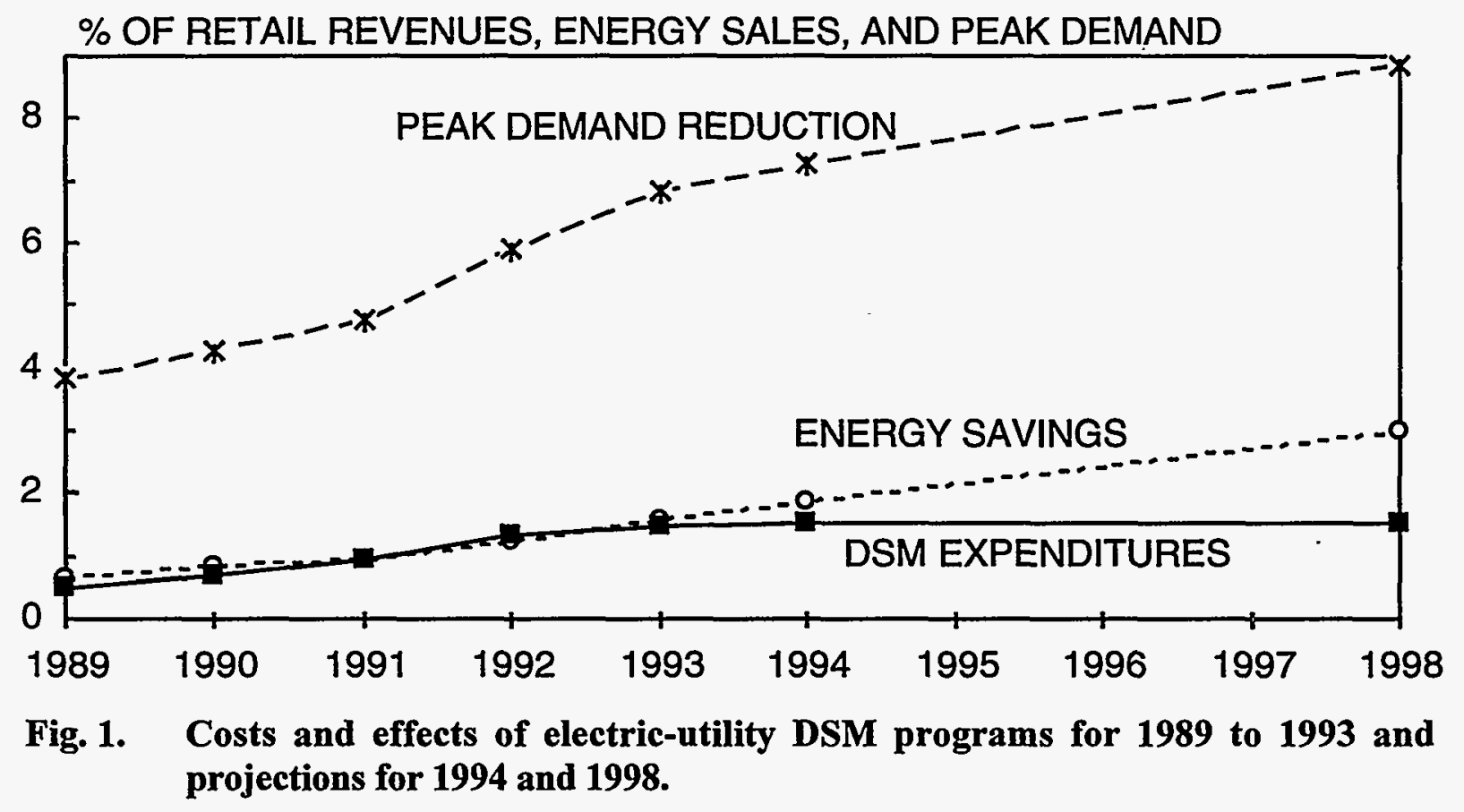

- The national totals from Edison Electric Institute (EEI) are $\$ 192.9$ billion of retail revenues and $2,797,000 \mathrm{GWh}$ of retail sales (EEI 1994). The peak summer demand for 1993. is 580,753 MW (NERC 1994). 
Table 2. Annual costs and effects of electric-utility DSM programs, 1989 to 1998

\begin{tabular}{|c|c|c|c|c|c|c|c|}
\hline & \multicolumn{3}{|c|}{ Program Cost } & \multicolumn{2}{|c|}{ Energy Savings } & \multicolumn{2}{|c|}{$\begin{array}{c}\text { Potential Peak- } \\
\text { Demand Reductionb } \\
\end{array}$} \\
\hline & & (million & & & & & \\
\hline & (million \$) & 1993\$) & $\% a$ & (GWh/year) & $\% \mathrm{a}$ & $(\mathrm{MW})$ & $\% \mathrm{a}$ \\
\hline 1989 & 870 & 1,014 & 0.5 & 16,300 & 0.6 & 20,100 & $\overline{3.8}$ \\
\hline \multicolumn{8}{|l|}{1990} \\
\hline Totals & 1,180 & 1,300 & 0.7 & 22,400 & 0.8 & 23,300 & 4.3 \\
\hline Investor-owned & 1,060 & 1,170 & 0.8 & 16,900 & 0.6 & 17,500 & 4.2 \\
\hline Consumer-owned & 120 & 130 & 0.3 & 5,500 & 0.9 & 5,800 & 4.6 \\
\hline \multicolumn{8}{|l|}{1991} \\
\hline Totals & 1,750 & 1,860 & 0.9 & 25,000 & 0.9 & 26,200 & 4.8 \\
\hline Investor-owned & 1,510 & 1,600 & 1.0 & 19,300 & 0.8 & 19,000 & 4.5 \\
\hline Consumer-owned & 240 & 260 & 0.6 & 5,700 & 0.9 & 7,200 & 5. \\
\hline \multicolumn{8}{|l|}{1992} \\
\hline Totals & 2,490 & 2,560 & 1.3 & 34,000 & 1.2 & 32,500 & 5.9 \\
\hline Investor-owned & 2,020 & 2,080 & 1.4 & 25,900 & 1.2 & 23,800 & 5. \\
\hline Consumer-owned & 470 & 480 & 1.2 & 8,100 & 1.3 & 8,700 & 6.9 \\
\hline \multicolumn{8}{|l|}{1993} \\
\hline Totals & 2,820 & 2,820 & 1.5 & 44,300 & 1.6 & 39,600 & 6. \\
\hline Investor-owned & 2,300 & 2,300 & 1.5 & 35,100 & 1.6 & 28,100 & 6. \\
\hline Consumer-owned & 520 & 520 & 1.3 & 9,300 & 1.5 & 11,600 & 8.7 \\
\hline \multicolumn{8}{|l|}{1994 (projected) } \\
\hline Totals & 3,070 & 2,990 & 1.5 & 53,300 & 1.9 & 42,300 & 7.3 \\
\hline Investor-owned & 2,440 & 2,380 & 1.5 & 39,900 & 1.8 & 30,300 & 6.7 \\
\hline Consumer-owned & 630 & 610 & 1.5 & 13,400 & 2.1 & 12,000 & 9. \\
\hline \multicolumn{8}{|l|}{1998 (projected) } \\
\hline Totals & 3,630 & 3,190 & 1.5 & 90,100 & 3.0 & 55,300 & 8.9 \\
\hline Investor-owned & 2,820 & 2,480 & 1.5 & 63,700 & 2.7 & 40,300 & 8.4 \\
\hline Consumer-owned & 810 & 710 & 1.7 & 26,300 & 3.8 & 15,000 & 10.6 \\
\hline
\end{tabular}

a These percentages reflect, respectively, total U.S. retail electric revenue, retail electricity sales, and summer peak demand for 1989, 1990, 1991, 1992, and 1993, and projected values for 1994 and 1998.

b Utilities report to EIA estimates of actual and potential peak-demand reductions (23,200 MW vs 39,600 MW for 1993). The actual reductions are the amount of load shed during system peaks. The potential reductions represent the amount of load that the utility could have shed. The difference between the two numbers represents, as examples, interruptible contracts that were not exercised and load-control devices that were not activated. All the numbers presented in this report are potential estimates.

The data show continued growth in DSM expenditures, energy savings, and demand reductions through 1998. Expenditures are expected to grow around $2.5 \%$ per year over inflation, approximately the same as retail revenues, so DSM as a percentage of revenues stays flat at 
$1.5 \%$. Because DSM programs provide savings for several years, annual savings grow each year from the incremental savings from new programs. Energy savings show steady growth to $3.0 \%$ of sales in 1998. Potential peak reductions increase from $6.8 \%$ in 1993 to $8.9 \%$ in 1998 .

Comparing these results to the projections from the 1992 utility reports shows that 1993 expenditures were $6.5 \%$ below what was projected for the year. However, energy savings were only $2 \%$ below and peak demand savings were $9 \%$ above the projections. The current projections for 1998, when compared to last year's 1997 projections, show similar trends. When we extrapolate last year's 1997 data to 1998 , we find that current projections for spending are $20 \%$ below the extrapolation, but energy savings are essentially the same and peak savings are $4 \%$ above (Fig. 2).

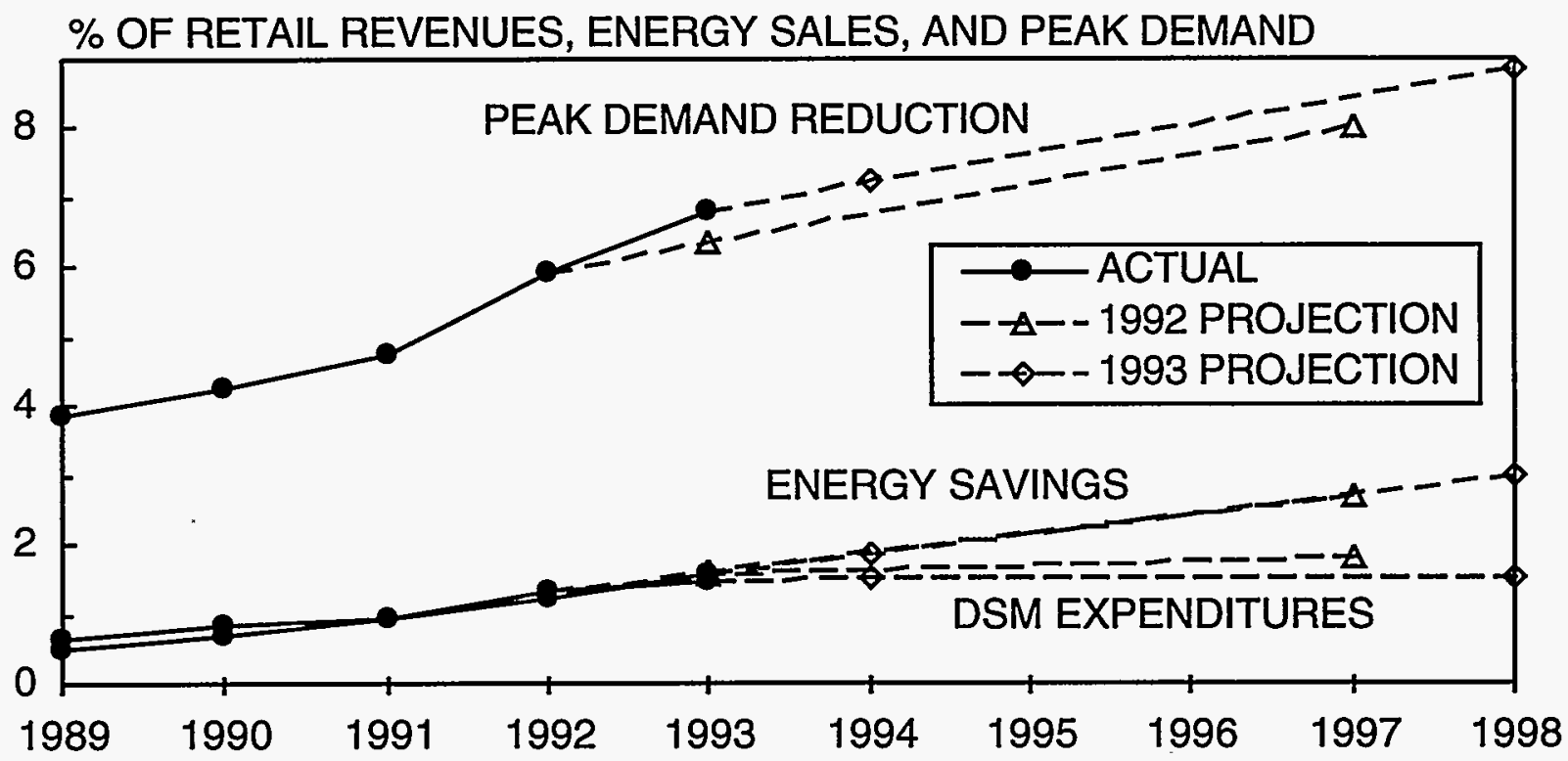

Fig. 2. 1992 and 1993 projections of DSM expenditures, annual energy savings, and peak demand savings.

IOUs continued to spend more as a proportion of revenues than COUs in 1993 (Table 2). IOU spending increased from $1.4 \%$ of sales in 1992 to $1.5 \%$ in 1993 . COU spending increased from $1.2 \%$ to $1.3 \%$ during the same period. The projections for 1994 and 1998 , however, show the COUs surpassing the IOUs in spending and in savings. This could be due to a number of factors. DSM has not penetrated the COU industry as rapidly as it did the IOUs, because of such factors as smaller size and less regulatory pressure. But COUs also have some natural incentives for DSM. Because they are owned by their customers, they may face less divergence of goals between customers and shareholders than IOUs face (although municipal bondholders may exert some influence.) Flanigan and Hadley (1994) describe the trends for DSM at publicly owned utilities in more detail. 
Utilities continued to spend most of their funds on energy-efficiency programs. As shown in Fig. 3, 70\% of funds were spent on efficiency programs such as weatherization, energy audits, and efficient lighting. The two major types of load-management programs, direct load control and interruptible rates, consumed $25 \%$ of the total, and other load management and DSM programs used the remaining 5\%. Energy savings largely came from the energy-efficiency programs, whereas the load-management programs had a much larger impact on peak reduction. This is to be expected based on the emphasis that the programs place on energy or demand reduction, respectively.

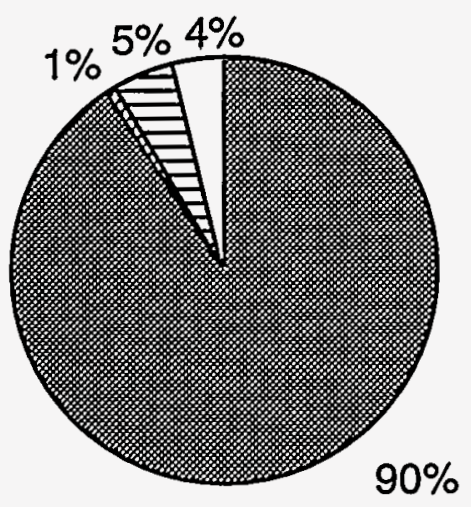

ENERGY SAVINGS

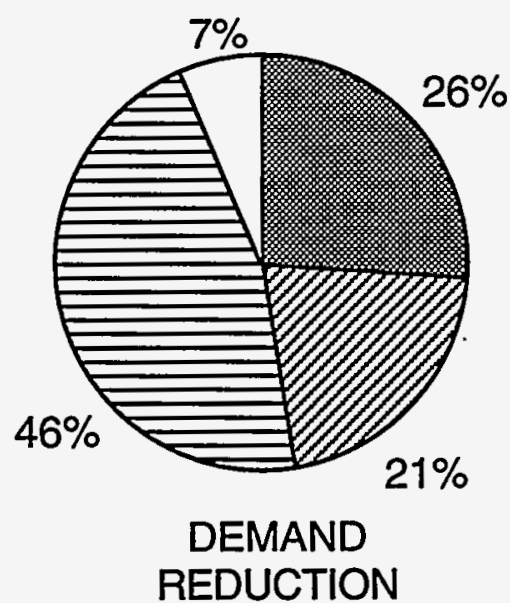

$39,600 \mathrm{MW}$

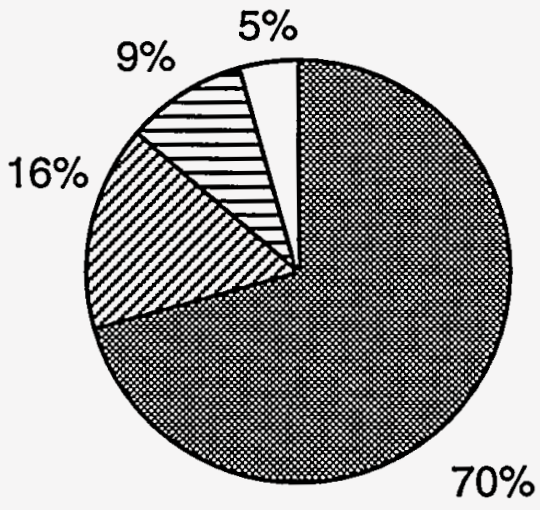

EXPENDITURES $\$ 2.82$ billion

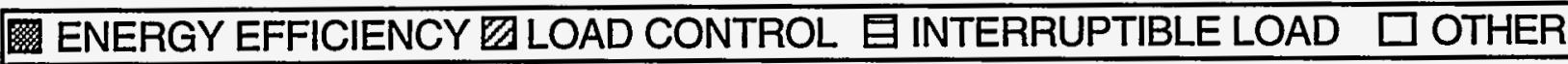

Fig. 3. 1993 DSM program expenditures and effects by program types. 



\section{DSM-PROGRAM EXPENDITURES}

In 1993, utilities spent $\$ 2.8$ billion on DSM programs. About $82 \%$ ( $\$ 2.3$ billion) was for direct program costs, with the remaining $18 \%$ ( $\$ 0.5$ billion) for indirect costs. This represents a decline in the relative amount of indirect costs, which were $22 \%$ of the total in 1992 . Over $70 \%$ of the costs in 1993 were devoted to energy-efficiency programs. In addition to utility costs, customers and other participants in DSM programs spent $\$ 0.4$ billion, bringing the grand total to $\$ 3.2$ billion. (The non-utility expenditures may be low because only 135 of the 991 utilities reported any.)

The distribution among utilities in DSM expenditures is not as skewed as in previous years. The three top utilities, Bonneville Power Administration (BPA), Pacific Gas \& Electric, and Florida Power and Light, alone accounted for almost $15 \%$ of the national total (Table 3), compared to $18 \%$ in 1992.

Twenty-one of the top 25 utilities were also among the top 25 for 1992 (Hirst 1994). The four additions for 1993 include BPA, Georgia Power, PacifiCorp, and PSI Energy. (BPA should have been in the 1992 list, but most of its DSM expenditures that year were reported through its power distributors or not reported at all.) These 25 utilities, of which 22 are IOUs, accounted for over $60 \%$ of the U.S. electric-utility expenditures on DSM in 1993; the top five utilities accounted for a full $25 \%$ of the industry's DSM expenditures. The 25 leading utilities spent $2.4 \%$ of their revenues on DSM, $60 \%$ higher than the national average. They also achieved $63 \%$ of the annual energy savings and $45 \%$ of the annual demand reduction for that year.

Because COUs, on average, are much smaller than IOUs, a display of the percentage of revenues spent on DSM shows a different picture than that presented by absolute expenditures (compare Tables 3 and 4). COUs account for 14 of the top 25 utilities in percentage of revenue spent on DSM in 1993. These 25 utilities spent 5.5\% of their revenues on DSM, more than three times the national average. (There may be some double counting of DSM between BPA and its distributors. BPA frequently reimburses distributor costs, so the programs may be claimed in both organizations' submittals. The EIA is currently exploring this.)

About $29 \%$ of the utilities spent less than $0.1 \%$ of revenues on DSM (Fig. 4). At the other end of the spectrum, $29 \%$ of the utilities spent more than $1 \%$ on such programs. These numbers represent the 574 utilities with over $120 \mathrm{GWh}$ of sales. The largest growth from 1992 to 1993 was in the number of utilities spending less than $0.1 \%$, from 117 to 167 utilities. The number of utilities spending more than $2 \%$ grew from 58 to 76 utilities. Among the full set of 991 utilities with DSM programs $37 \%$ spent less than $0.1 \%$ of revenues on DSM, because small utilities are less active in DSM than large utilities. 
Table 3. The 25 utilities with the largest 1993 DSM expenditures

\begin{tabular}{|c|c|c|c|c|c|c|c|c|c|c|c|c|c|c|c|}
\hline \multirow{3}{*}{ Utility } & \multirow{3}{*}{ State } & \multirow{3}{*}{ IOU } & \multirow{3}{*}{$\begin{array}{l}\text { Output } \\
\text { (GWh) }\end{array}$} & \multirow{3}{*}{$\begin{array}{r}\text { Peak } \\
(\mathrm{MW})\end{array}$} & \multirow{3}{*}{$\begin{array}{r}\text { Revenue } \\
(\mathrm{M} \$)\end{array}$} & \multicolumn{5}{|c|}{ Total DSM programs without load building } & \multicolumn{5}{|c|}{$1993 \mathrm{DSM}$ as \% of } \\
\hline & & & & & & \multicolumn{2}{|c|}{$\Delta$ Sales (GWh) } & \multicolumn{2}{|c|}{$\Delta$ Peak $(M W)$} & \multirow{2}{*}{$\begin{array}{l}\text { Cost } \\
(\mathrm{M} \$)\end{array}$} & \multirow{2}{*}{\multicolumn{2}{|c|}{$\frac{\text { Sales }}{\text { Incr'l Ann'l }}$}} & \multirow{2}{*}{\multicolumn{2}{|c|}{$\frac{\text { Peak }}{\text { Incr'l Ann'l }}$}} & \multirow{2}{*}{$\begin{array}{l}\text { Rev- } \\
\text { enue }\end{array}$} \\
\hline & & & & & & Incr'l & Ann'l & Incr'l & Ann'l & & & & & & \\
\hline Bonneville Power Admin & WA & & 79125 & 15662 & 1864 & 575 & 2076 & 0 & 177 & 165 & 0.7 & 2.6 & 0.0 & 1.1 & 8.9 \\
\hline Pacific Gas \& Electric & $\mathrm{CA}$ & $\mathrm{Y}$ & 81853 & 14314 & 7878 & 547 & 1610 & 669 & 909 & 142 & 0.7 & 2.0 & 4.7 & 6.4 & 1.8 \\
\hline Florida Power \& Light & FL & Y & 78179 & 15266 & 5224 & 166 & 2738 & 169 & 1331 & 139 & 0.2 & 3.5 & 1.1 & 8.7 & 2.7 \\
\hline Southern California Edison & $\mathrm{CA}$ & $Y$ & 81328 & 16475 & 7387 & 970 & 6113 & 355 & 3020 & 128 & 1.2 & 7.5 & 2.2 & 18.3 & 1.7 \\
\hline Consolidated Edison & $\mathrm{NY}$ & $\mathrm{Y}$ & 39894 & 9059 & 5145 & 522 & 498 & 221 & 213 & 125 & 1.3 & 1.2 & 2.4 & 2.4 & 2.4 \\
\hline Florida Power Corp & FL & $\mathbf{Y}$ & 30669 & 6729 & 1958 & 67 & 989 & 153 & 1438 & 103 & 0.2 & 3.2 & 2.3 & 21.4 & 5.3 \\
\hline Duke Power & $\mathrm{NC}$ & $\mathrm{Y}$ & 80672 & 15049 & 4282 & 39 & 74 & 204 & 1521 & 86 & 0.0 & 0.1 & 1.4 & 10.1 & 2.0 \\
\hline Potomac Electric Power & $\mathrm{DC}$ & $Y$ & 27642 & 5754 & 1725 & 228 & 431 & 74 & 375 & 74 & 0.8 & 1.6 & 1.3 & 6.5 & 4.3 \\
\hline Baltimore Gas \& Electric & $\mathrm{MD}$ & $\mathrm{Y}$ & 32550 & 5876 & 2115 & 105 & 190 & 187 & 523 & 66 & 0.3 & 0.6 & 3.2 & 8.9 & 3.1 \\
\hline New York State Elec \& Gas & NY & $\mathbf{Y}$ & 20942 & 2517 & 1527 & 285 & 695 & 52 & 158 & 64 & 1.4 & 3.3 & 2.1 & 6.3 & 4.2 \\
\hline Puget Sound Power \& Light & WA & $\mathrm{Y}$ & 21198 & 4411 & 1113 & 260 & 1490 & 14 & 41 & 60 & 1.2 & 7.0 & 0.3 & 0.9 & 5.4 \\
\hline Wisconsin Electric Power & WI & $\mathrm{Y}$ & 27204 & 4691 & 1348 & 345 & 1286 & 92 & 435 & 58 & 1.3 & 4.7 & 2.0 & 9.3 & 4.3 \\
\hline Boston Edison & MA & $\mathrm{Y}$ & 16689 & 2662 & 1477 & 72 & 382 & 11 & 101 & 57 & 0.4 & 2.3 & 0.4 & 3.8 & 3.8 \\
\hline Valley Authority & $\mathrm{TN}$ & & 128729 & 23878 & 5349 & 26 & 3266 & 14 & 4235 & 56 & 0.0 & 2.5 & 0.1 & 17.7 & 1.1 \\
\hline Massachusetts Electric & MA & $\mathrm{Y}$ & 16192 & 2819 & 1469 & 115 & 549 & 33 & 147 & 53 & 0.7 & 3.4 & 1.2 & 5.2 & 3.6 \\
\hline Consumers Power & MI & $Y$ & 35484 & 6226 & 2077 & 289 & 280 & 100 & 135 & 53 & 0.8 & 0.8 & 1.6 & 2.2 & 2.5 \\
\hline Georgia Power & GA & $\mathrm{Y}$ & 79531 & 12573 & 4451 & 52 & 134 & 109 & 380 & 52 & 0.1 & 0.2 & 0.9 & 3.0 & 1.2 \\
\hline Public Service Electric\&Gas & $\mathrm{NJ}$ & $\mathrm{Y}$ & 43221 & 6145 & 3693 & 57 & 57 & 204 & 368 & 50 & 0.1 & 0.1 & 3.3 & 6.0 & 1.4 \\
\hline Niagara Mohawk Power & NY & $Y$ & 40811 & 6146 & 3308 & 218 & 737 & 32 & 135 & 47 & 0.5 & 1.8 & 0.5 & 2.2 & 1.4 \\
\hline Carolina Power \& Light & NC & $\mathrm{Y}$ & 47476 & 9107 & 2895 & 78 & 2062 & 80 & 1375 & 42 & 0.2 & 4.3 & 0.9 & 15.1 & 1.5 \\
\hline San Diego Gas \& Electric & $\mathrm{CA}$ & $\mathrm{Y}$ & 17227 & 3853 & 1514 & 0 & 134 & 4 & 57 & 42 & 0.0 & 0.8 & 0.1 & 1.5 & 2.8 \\
\hline Connecticut Light \& Power & $\mathrm{CT}$ & $Y$ & 27896 & 4257 & 2366 & 126 & 1160 & 22 & 267 & 41 & 0.5 & 4.2 & 0.5 & 6.3 & 1.7 \\
\hline PacifiCorp & OR & $\mathrm{Y}$ & 61995 & 7591 & 2506 & 145 & 678 & 0 & 300 & 41 & 0.2 & $1: 1$ & 0.0 & 4.0 & 1.6 \\
\hline Sacramento Muni Util Dist & $\mathrm{CA}$ & & 9051 & 2185 & 617 & 96 & 269 & 35 & 309 & 36 & 1.1 & 3.0 & 1.6 & 14.1 & 5.9 \\
\hline PSI Energy & $\mathbb{N}$ & $\mathrm{Y}$ & 28062 & 4812 & 1078 & 143 & 141 & 61 & 76 & 35 & 0.5 & 0.5 & 1.3 & 1.6 & 3.3 \\
\hline Totals top 25 & & & 1153621 & 208056 & 74366 & 5526 & 28039 & 2895 & 18024 & 1817 & 0.5 & 2.4 & 1.4 & 8.7 & 2.4 \\
\hline Top 25 as $\%$ of national total & & & 27 & 36 & 30 & 61 & 63 & 39 & 45 & 64 & & & & & \\
\hline
\end{tabular}


Table 4. The 25 utilities with the largest 1993 DSM expenditures as a percentage of revenue

\begin{tabular}{|c|c|c|c|c|c|c|c|c|c|c|c|c|c|c|c|}
\hline \multirow{3}{*}{ Utility } & \multirow{3}{*}{ State } & \multirow{3}{*}{ IOU } & \multirow{3}{*}{$\begin{array}{l}\text { Output } \\
\text { (GWh) }\end{array}$} & \multirow{3}{*}{$\begin{array}{r}\text { Peak } \\
(\mathrm{MW}) \\
\end{array}$} & \multirow{3}{*}{$\begin{array}{r}\text { Revenue } \\
\text { (M\$) }\end{array}$} & \multicolumn{5}{|c|}{ Total DSM programs without load building } & \multicolumn{5}{|c|}{1993 DSM as \% of } \\
\hline & & & & & & \multicolumn{2}{|c|}{$\Delta$ Sales (GWh) } & \multicolumn{2}{|c|}{$\Delta$ Peak (MW) } & \multirow{2}{*}{$\begin{array}{l}\text { Cost } \\
(\mathrm{M} \$)\end{array}$} & \multirow{2}{*}{\multicolumn{2}{|c|}{$\begin{array}{c}\text { Sales } \\
\text { Incr'l Ann'l }\end{array}$}} & \multirow{2}{*}{\multicolumn{2}{|c|}{$\frac{\text { Peak }}{\text { Incr'l Ann'l }}$}} & \multirow{2}{*}{$\begin{array}{l}\text { Rev- } \\
\text { enue }\end{array}$} \\
\hline & & & & & & Incr'1 & Ann'l & Incr'1 & Ann'l & & & & & & \\
\hline Gaffney, City of & SC & & 196 & 45 & 11 & 0 & 0 & 0.2 & 0.1 & 2 & 0.0 & 0.0 & 0.5 & 0.3 & 16.7 \\
\hline Bonneville Power Admin & WA & & 79125 & 15662 & 1864 & 575 & 2076 & 0 & 177 & 165 & 0.7 & 2.6 & 0.0 & 1.1 & 8.9 \\
\hline Seattle, City of & WA & & 9475 & 1837 & 334 & 51 & 334 & 6 & 38 & 24 & 0.5 & 3.5 & 0.3 & 2.1 & 7.1 \\
\hline Port Angeles, City of & WA & & 655 & 129 & 20 & 2 & 15 & 0.1 & 1 & 1 & 0.3 & 2.2 & 0.1 & 0.6 & 6.9 \\
\hline Tacoma, City of & WA & & 6183 & 994 & 200 & 57 & 271 & 0 & 0 & 12 & 0.9 & 4.4 & 0.0 & 0.0 & 6.2 \\
\hline Sacramento Muni Util Dist & $\mathrm{CA}$ & & 9051 & 2185 & 617 & 96 & 269 & 35 & 309 & 36 & 1.1 & 3.0 & 1.6 & 14.1 & 5.9 \\
\hline Springfield, City of & OR & & 832 & 176 & 29 & 6 & 54 & 0.1 & 1 & 2 & 0.7 & 6.5 & 0.1 & 0.7 & 5.7 \\
\hline Green Mountain Power Corp & VT & $\mathrm{Y}$ & 2157 & 307 & 147 & 20 & 30 & 5 & 21 & 8 & 0.9 & 1.4 & 1.7 & 6.9 & 5.7 \\
\hline Washington Water Power & WA & $\mathbf{Y}$ & 11029 & 1521 & 464 & 153 & 391 & 54 & 103 & 25 & 1.4 & 3.5 & 3.6 & 6.8 & 5.4 \\
\hline Wabash Valley Power Assn & $\mathbb{N}$ & & 3932 & 847 & 161 & 0 & 0 & 3 & 50 & 9 & 0.0 & 0.0 & 0.4 & 5.9 & 5.4 \\
\hline Puget Sound Power \& Light & WA & $\mathrm{Y}$ & 21198 & 4411 & 1113 & 260 & 1490 & 14 & 41 & 60 & 1.2 & 7.0 & 0.3 & 0.9 & 5.4 \\
\hline Wisconsin Public Service & WI & $\mathrm{Y}$ & 10772 & 1548 & 493 & 113 & 322 & 36 & 121 & 26 & 1.0 & 3.0 & 2.3 & 7.8 & 5.3 \\
\hline Florida Power Corp & FL & $\mathbf{Y}$ & 30669 & 6729 & 1958 & 67 & 989 & 153 & 1438 & 103 & 0.2 & 3.2 & 2.3 & 21.4 & 5.3 \\
\hline Orange \& Rockland Utils & NY & $Y$ & 4947 & 1037 & 42.1 & 44 & 167 & 23 & 98 & 22 & 0.9 & 3.4 & 2.2 & 9.5 & 5.2 \\
\hline Mid-Carolina Electric Coop & SC & & 646 & 153 & 42 & 1 & 2 & 1 & 6 & 2 & 0.1 & 0.4 & 0.5 & 4.2 & 5.1 \\
\hline Eugene, City of & OR & & 2919 & 568 & 107 & 22 & 156 & 4 & 33 & 5 & 0.8 & 5.4 & 0.6 & 5.7 & 5.0 \\
\hline Lynches River Elec Coop & SC & & 237 & 59 & 16 & 0.1 & 1 & 0.3 & 2 & 1 & 0.1 & 0.3 & 0.6 & 4.0 & 4.5 \\
\hline Madison Gas \& Electric & WI & $\mathbf{Y}$ & 2557 & 541 & 148 & 28 & 90 & 13 & 42 & 7 & 1.1 & 3.5 & 2.3 & 7.7 & 4.5 \\
\hline PUD No 1, Snohomish Cty & WA & & 6190 & 1466 & 275 & 53 & 270 & 9 & 48 & 12 & 0.9 & 4.4 & 0.6 & 3.2 & 4.5 \\
\hline Boulder City, City of & NV & & 141 & 40 & 5 & 1 & 0 & 3 & 0 & 0 & 0.6 & 0.0 & 8.2 & 0.0 & 4.4 \\
\hline Western Massachusetts Elec & MA & $\mathrm{Y}$ & 5028 & 696 & 415 & 44 & 202 & 11 & 59 & 18 & 0.9 & 4.0 & 1.5 & 8.4 & 4.4 \\
\hline Wisconsin Electric Power & WI & $\mathbf{Y}$ & 27204 & 4691 & 1348 & 345 & 1286 & 92 & 435 & 58 & 1.3 & 4.7 & 2.0 & 9.3 & 4.3 \\
\hline Potomac Electric Power & $\mathrm{DC}$ & $Y$ & 27642 & 5754 & 1725 & 228 & 431 & 74 & 375 & 74 & 0.8 & 1.6 & 1.3 & 6.5 & 4.3 \\
\hline New York State Elec \& Gas & $N Y$ & $\mathrm{Y}$ & 20942 & 2517 & 1527 & 285 & 695 & 52 & 158 & 64 & 1.4 & 3.3 & 2.1 & 6.3 & 4.2 \\
\hline Columbia River Peoples Ut & OR & & 281 & 55 & 12 & 2 & 4 & 0 & 0 & 0.5 & 0.6 & 1.4 & 0.0 & 0.0 & 4.1 \\
\hline Totals top 25 & & & 284,008 & 53,967 & 13,452 & 2,453 & 9,545 & 588 & 3,555 & 737 & 0.9 & 3.4 & 1.1 & 6.6 & 5.5 \\
\hline Top 25 as \% of national totals & & & 7 & 9 & 5 & 27 & 22 & 8 & 9 & 26 & & & & & \\
\hline
\end{tabular}


For the top 25 utilities in 1993 DSM expenditures, the changes in spending from 1992 to 1993 and from 1993 to 1994 show no distinct pattern (Fig. 5). Of these 25 utilities, nine cut their DSM expenditures between 1992 and 1993, while 16 increased expenditures. The most dramatic changes were for Georgia Power ( $+\$ 46$ million), Florida Power \& Light ( $+\$ 44$ million), and Southern California Edison ( $\$ 41$ million); and for Pacific Gas \& Electric (-\$76 million) and Niagara Mohawk (-\$29 million).

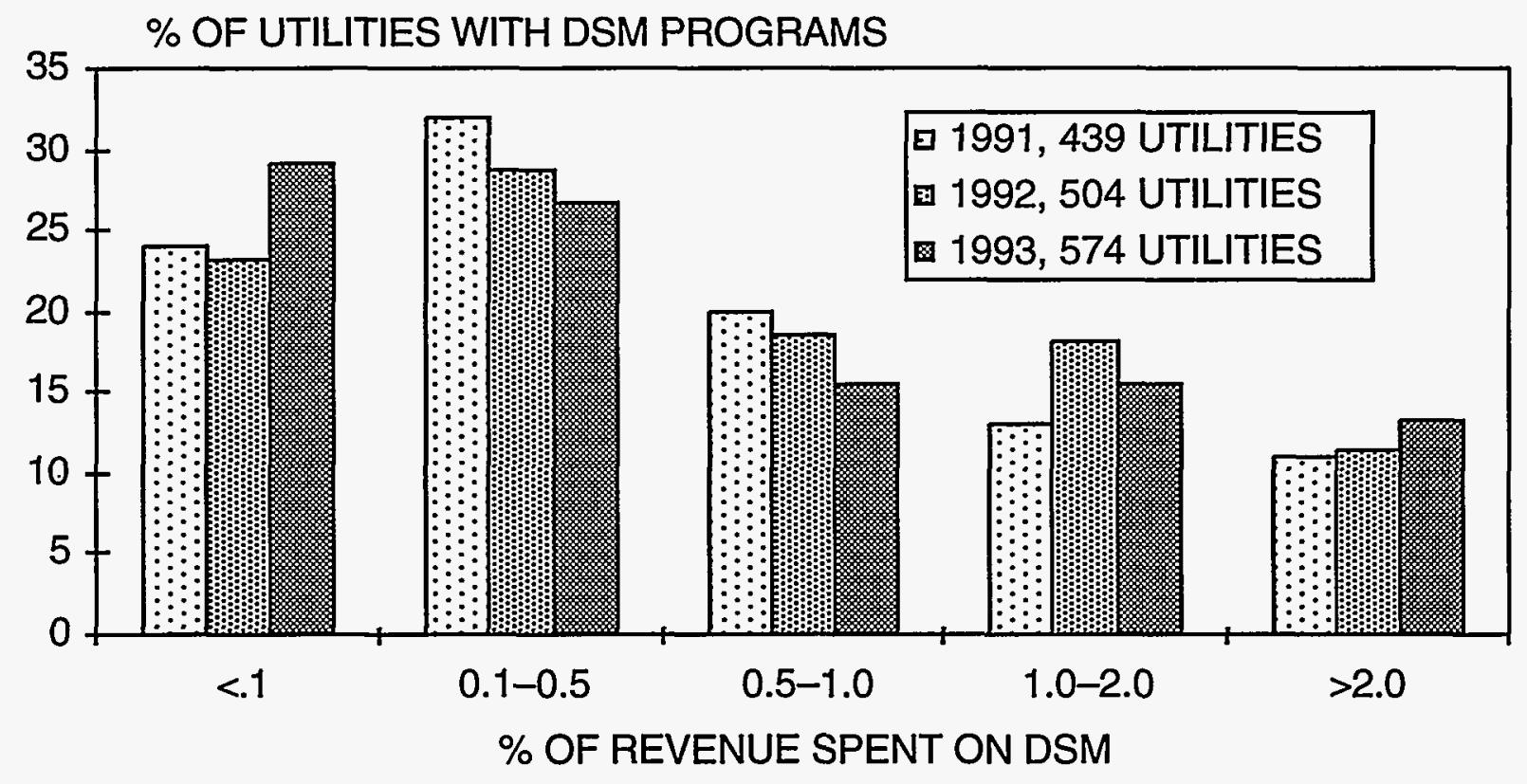

Fig. 4. Distribution of utilities with sales over $120 \mathrm{GWh}$ that have DSM programs by percentage of total revenues spent on DSM.

Between 1993 and 1994, nine of these 25 utilities planned to cut their DSM expenditures and 16 planned to increase spending on DSM. Only three utilities (New York State Electric \& Gas, Niagara Mohawk, and Connecticut Light \& Power) showed declines for both years. On the other hand, 10 utilities showed increases in expenditures for both 1993 and 1994. Between 1992 and 1994, 15 of the utilities increased their DSM expenditures, while ten decreased their budgets. Overall, these 25 utilities showed increases in DSM expenditures from 1992 to 1993 and from 1993 to 1994 , just as the national totals showed.

The utilities in eight states-California, Florida, Massachusetts, Maryland, North Carolina, New York, Washington, and Wisconsin-spent more than $\$ 100$ million on their DSM programs in 1993.* On average, the utilities in Connecticut, the District of Columbia, Florida,

* For several reasons, readers should be cautious about the state results presented here. First, for utilities that operate in more than one state, we assumed that the DSM costs and effects were allocated the same way that retail sales were. But for some utilities (e.g., PacifiCorp) that face different regulatory policies in its states, this 
Idaho, Maryland, Massachusetts, Montana, New York, Oregon, Rhode Island, Vermont, Washington, and Wisconsin spent more than 2\% of revenues on DSM in 1993 (Fig. 6). Of these 13 states, two (Idaho and Maryland) are new to the list. Of the states with $>2 \%$ of revenues in 1992 , only California dropped below $2 \%$ of revenues in 1993. Fig. 7 shows the percentage change in DSM expenditures for each state. Twenty-eight states had increases over $10 \%$ in DSM spending, with 11 of them having over $50 \%$ increases. Only six states saw declines over $10 \%$.

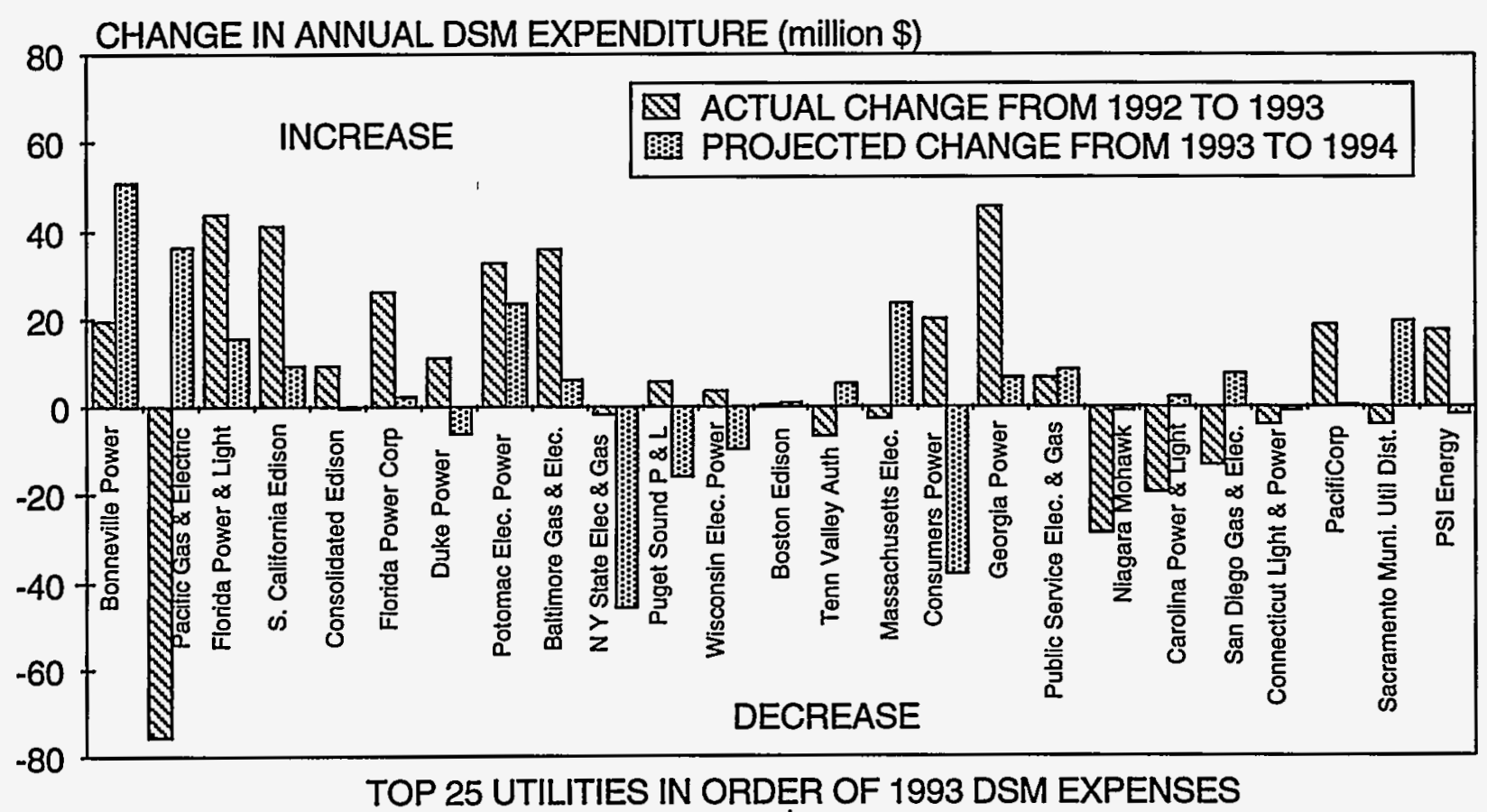

Fig. 5. Changes in DSM spending for the 25 highest-spending utilities in 1993.

allocation may not be correct. Second, we could find no state-level data on peak demands. Our assignment of state peaks is based on state energy sales converted to peak demands based on regional load factors reconciled to the NERC report of national peak demand. 


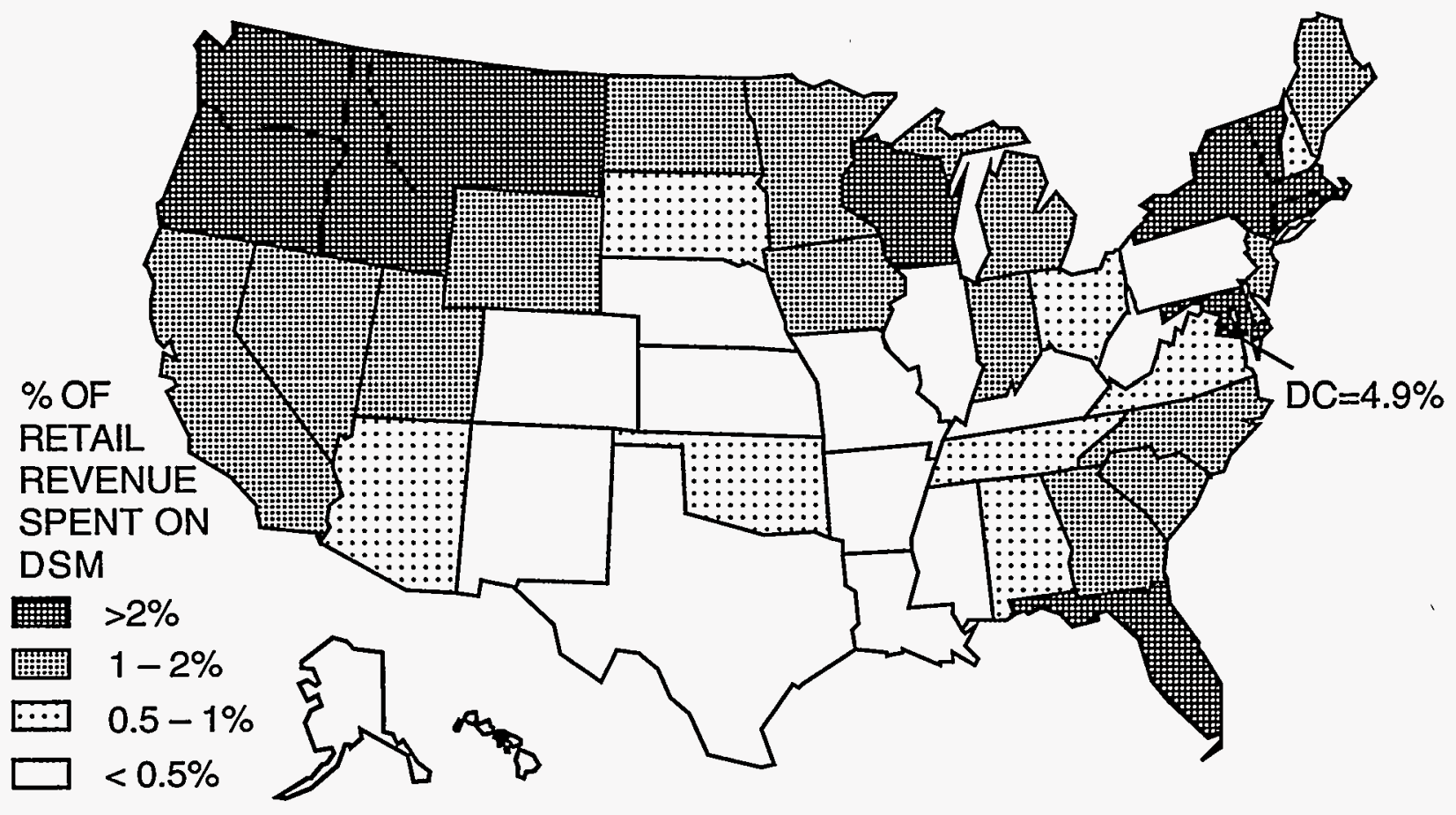

Fig. 6. Percentage of retail revenue spent on DSM programs by state in 1993.

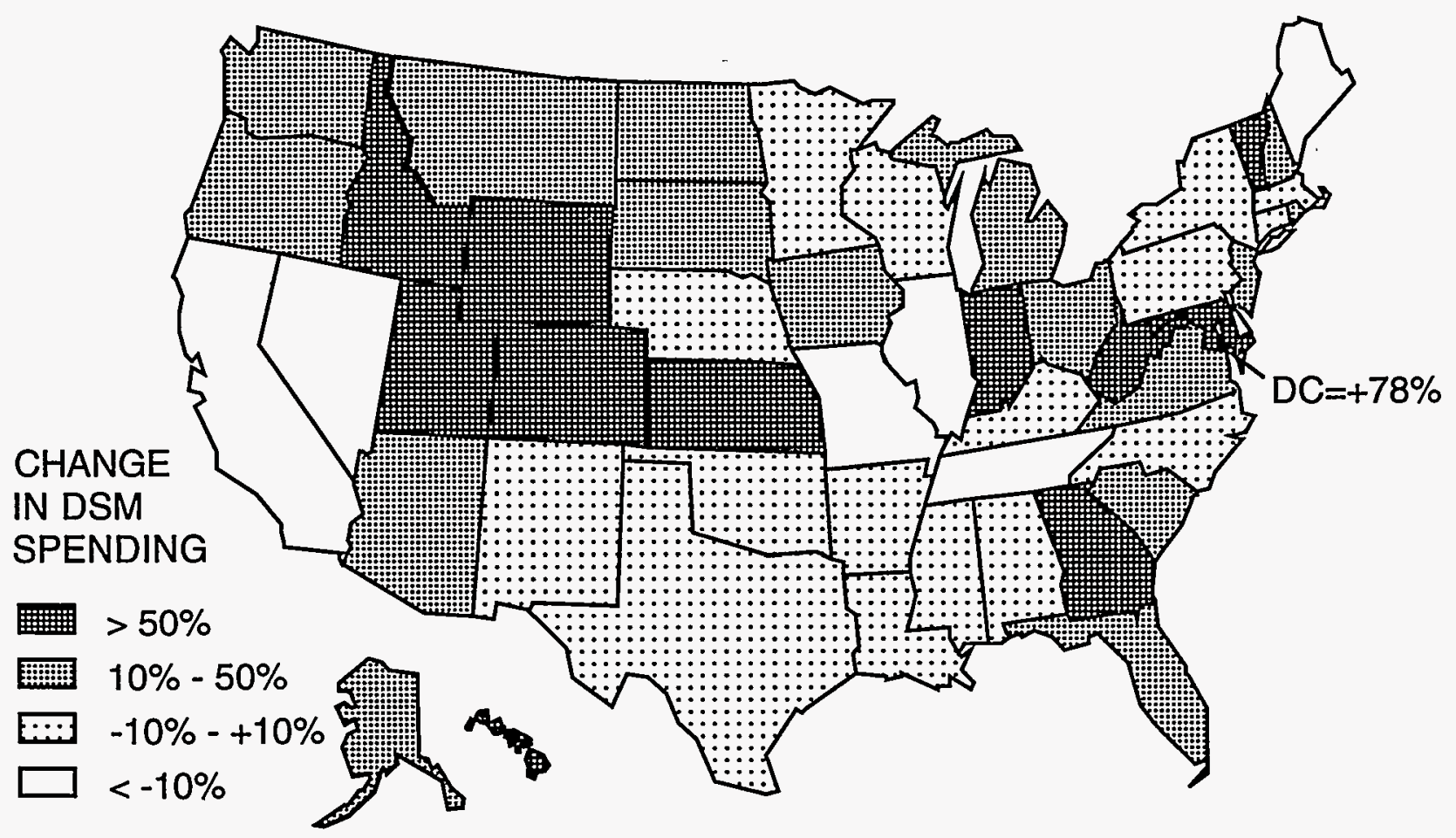

Fig. 7. Percentage change in DSM expenditures between 1992 and 1993. 


\section{DSM-PROGRAM ENERGY SAVINGS}

EIA requested utilities that sold more than $120 \mathrm{GWh}$ in 1993 to estimate both their incremental and annual energy savings. Incremental savings are the annualized savings achieved by those customers that began participation in 1993, while annual energy savings are the savings in 1993 caused by all prior and current participants in the utility's DSM programs. Annual savings in 1993 amounted to $44,300 \mathrm{GWh}, 1.6 \%$ of retail sales. Incremental savings were reported at $9,100 \mathrm{GWh}, 21 \%$ of annual savings.

Energy-efficiency programs accounted for the vast majority ( $94 \%$ of incremental and $90 \%$ of annual) of total savings. Dividing the levelized utility cost of these programs by the incremental savings caused by energy-efficiency programs yields a $3.0 \mathrm{k} / \mathrm{kWh}$ average cost of conserved electricity. Including the customer costs of DSM raises the total to $3.4 \phi / \mathrm{kWh}$. These estimates assume a 10-year lifetime of the efficiency measures and a real discount rate of $5 \%$. If the DSM measures last, on average, only five years, the utility cost of conserved energy is $5.3 \phi / \mathrm{kWh}$; if the measures last 15 years, the cost drops to $2.2 \mathrm{k} / \mathrm{kWh}$. (Changes in the discount rate have much less effect on the cost than does the estimated lifetime of the measures.)

The 1993 average cost $(3.0 \phi / \mathrm{kWh})$ is much lower than the 1992 figure $(4.0 \phi / \mathrm{kWh})$ when using the same 10-year lifetime and $5 \%$ discount rate. This difference is caused by the $60 \%$ jump in incremental energy saved by energy-efficiency programs from 1992 to 1993, compared to the $26 \%$ jump in direct costs and $6 \%$ drop in indirect costs. Clearly, utilities have become more costeffective in implementing energy-efficiency programs.

These calculations are a generalization in that they assign all of this year's costs for energy-efficiency programs to the increment added this year. This implies that all costs are in the first year. For capital-intensive programs this is largely correct, but there usually are some follow-on and monitoring costs that occur in later years. How much of this year's costs should apply to previous years' programs, and how much additional cost this year's programs will require is unknown. These figures represent the gross average of all energy-efficiency programs conducted in 1993. The actual costs of each program could be very different, both because of its specific costs and the lifetime of the measures installed.

For other reasons, readers should view these cost figures cautiously. As Joskow and Marron (1992) pointed out, some utilities may ignore various costs (e.g, those borne by participating customers) and overestimate benefits (e.g., by using engineering estimates of energy savings) in their calculations of DSM-program cost effectiveness. Many utilities are not required to substantiate the nonutility costs to the extent of their own because only their own are to be recovered through electricity rates. (Only $14 \%$ of the utilities reported any nonutility costs.) 
Utilities have widely differing ways to recover program costs, which can affect calculations of cost of conserved electricity.

The residential sector accounted for $43 \%$ of the annual DSM-induced savings, much more than its $35 \%$ of retail sales (Fig. 8). The industrial sector, on the other hand, accounted for a smaller share of energy savings than of retail sales. Incremental savings, however, paint a different picture. As with the 1992 data, the commercial sector dominates, with both the residential and industrial sectors accounting for smaller shares of savings than of sales. These comparisons show that the historical focus of DSM programs on the residential sector continues to shift to the commercial sector. Meanwhile, the industrial sector continues to get less attention in terms of energy savings.

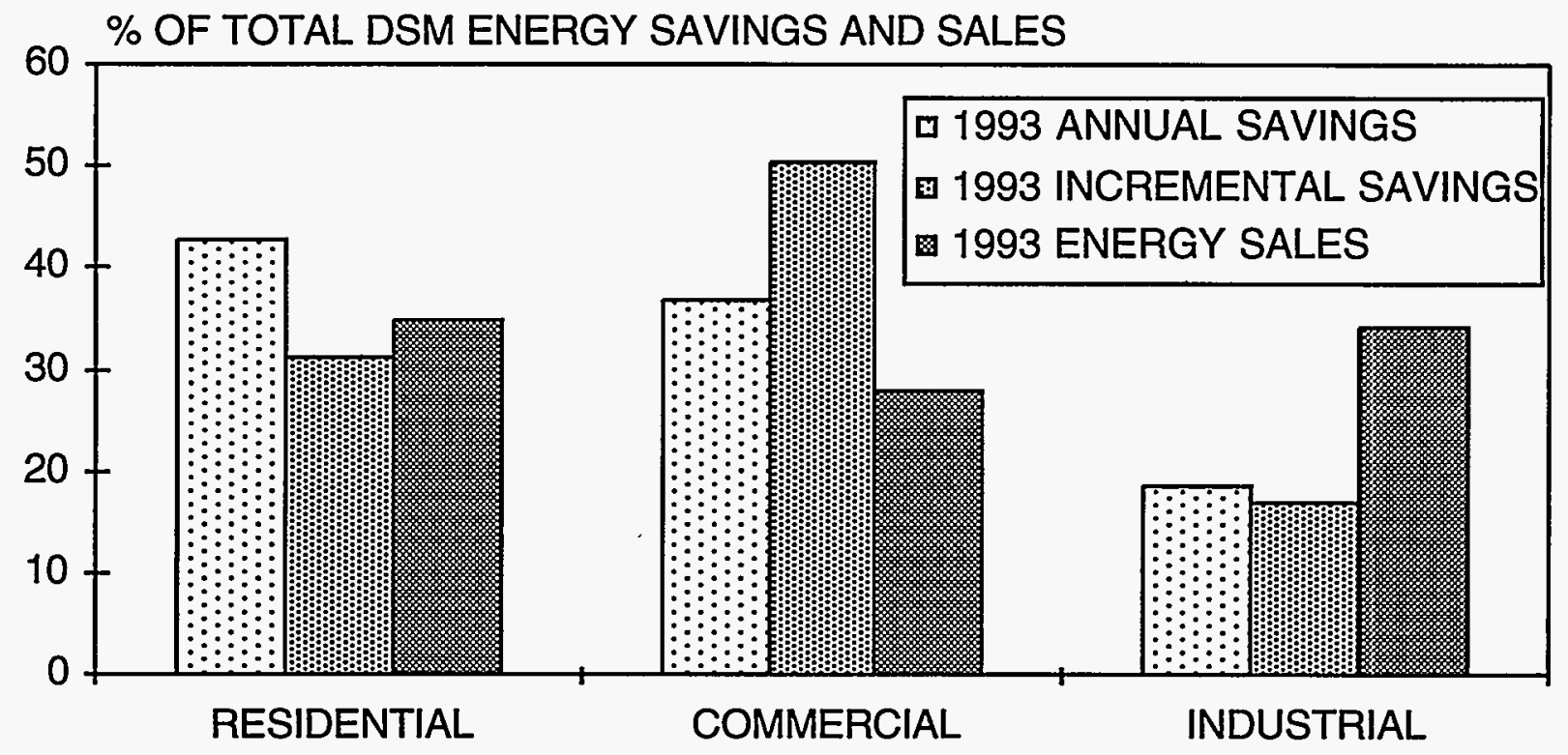

Fig. 8. Shares of 1993 annual energy savings (effects of all DSM programs), incremental energy savings (effects of 1993 programs), and energy sales by customer class.

As was true in past years, the distribution across utilities in DSM-induced annual savings is more skewed than the distribution of DSM-program costs (compare Figs. 4 and 9). Around $55 \%$ of the utilities reported savings of less than $0.1 \%$ of total sales in 1993 . At the other end of the spectrum, about $10 \%$ reported savings of $2 \%$ or more. However, a higher percentage of utilities are achieving greater savings than in past years. As programs mature and additional programs are introduced, the total savings from all programs increase.

Table 5 lists the 25 utilities that reported the largest annual savings caused by their DSM programs. Twenty of these utilities were among the top 25 for 1992 also. The additions for 1993 include Texas Utilities, Public Service Company of Colorado, New York State Electric \& Gas, 
Potomac Electric Power, and Washington Water Power. These 25 utilities, 22 of which are IOUs, account for three-fourths of the total U.S. annual savings. These utilities also account for almost half of the annual demand reduction and more than half of the utility DSM expenditures. Overall, these utilities cut annual electricity use by $3.0 \%$, about double the U.S. average. Sixteen of these utilities were also among the top 25 in expenditures.

Of the top 25 utilities in terms of annual energy savings for 1993, 17 also made the top 25 for incremental savings. Some of those that do not have large incremental amounts have had programs for a long time and have built up their annual savings over time (e.g., Tennessee Valley Authority, City of Austin). It is also possible that reporting errors account for a few of the differences. For example, Public Service Company of Colorado, a new entrant in the top 25, showed zero incremental savings.

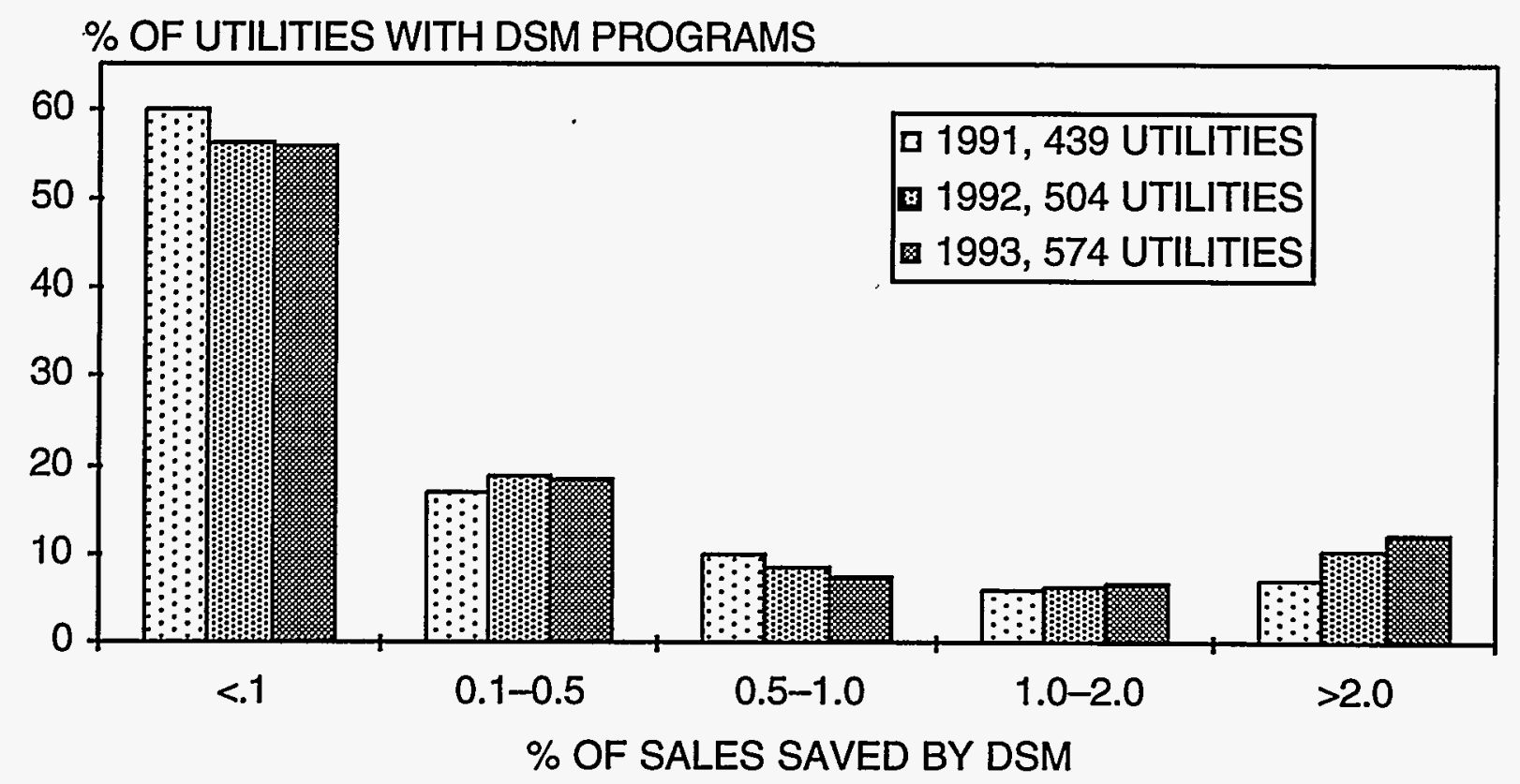

Fig. 9. Distribution of the utilities with sales over $120 \mathrm{GWh}$ that have DSM programs by percentage of energy saved by those programs.

The eight utilities that ranked among the top 25 in terms of incremental, but not annual, savings include Baltimore Gas \& Electric, Consumers Power, Detroit Edison, Portland General Electric, PSI Energy, Sierra Pacific Power, Southeastern Illinois Electric Coop., and Wisconsin Public Service. In time, they could be expected to advance in standing to the top 25 for annual savings. Three of the 11 utilities that were in the 1992 list of top utilities with regard to incremental but not annual savings are now in the 1993 list of top utilities for annual savings (New York State Electric \& Gas, Potomac Electric Power, and Sacramento Municipal Utility District). Four of the top 25 utilities in incremental savings (Consolidated Edison, Consumers Power, PSI Energy, and Detroit Edison) reported higher incremental than annual savings. This is 
Table 5. The 25 utilities with the largest 1993 annual energy savings caused by DSM

\begin{tabular}{|c|c|c|c|c|c|c|c|c|c|c|c|c|c|c|c|}
\hline \multirow{3}{*}{ Utility } & \multirow{3}{*}{ State } & \multirow{3}{*}{ IOU } & \multirow{3}{*}{$\begin{array}{l}\text { Output } \\
\text { (GWh) }\end{array}$} & \multirow{3}{*}{$\begin{array}{l}\text { Peak } \\
(M W)\end{array}$} & \multirow{3}{*}{$\begin{array}{r}\text { Revenue } \\
(\mathrm{M} \$)\end{array}$} & \multicolumn{5}{|c|}{ Total DSM programs without load building } & \multicolumn{5}{|c|}{1993 DSM as \% of } \\
\hline & & & & & & \multicolumn{2}{|c|}{$\Delta$ Sales (GWh) } & \multicolumn{2}{|c|}{$\Delta$ Peak (MW) } & \multirow{2}{*}{$\begin{array}{l}\text { Cost } \\
(\mathrm{M} \$)\end{array}$} & \multirow{2}{*}{\multicolumn{2}{|c|}{$\begin{array}{c}\text { Sales } \\
\text { Incr'l Ann'l }\end{array}$}} & \multirow{2}{*}{\multicolumn{2}{|c|}{$\frac{\text { Peak }}{\text { Incr'l Ann'l }}$}} & \multirow{2}{*}{$\begin{array}{l}\text { Rev- } \\
\text { enue }\end{array}$} \\
\hline & & & & & & Incr'l & Ann'l & Incr'l & Ann'l & & & & & & \\
\hline Southern California Edison & $\mathrm{CA}$ & $\mathbf{Y}$ & 81328 & 16475 & 7387 & 970 & 6113 & 355 & 3020 & 128 & 1.2 & 7.5 & 2.2 & 18.3 & 1.7 \\
\hline Tennessee Valley Authority & $\mathrm{TN}$ & & 128729 & 23878 & 5349 & 26 & 3266 & 14 & 4235 & 56 & 0.0 & 2.5 & 0.1 & 17.7 & 1.1 \\
\hline Florida Power \& Light & FL & $\mathrm{Y}$ & 78179 & 15266 & 5224 & 166 & 2738 & 169 & 1331 & 139 & 0.2 & 3.5 & 1.1 & 8.7 & 2.7 \\
\hline Bonneville Power Admin & WA & & 79125 & 15662 & 1864 & 575 & 2076 & 0 & 177 & 165 & 0.7 & 2.6 & 0.0 & 1.1 & 8.9 \\
\hline Carolina Power \& Light & NC & $\mathbf{Y}$ & 47476 & 9107 & 2895 & 78 & 2062 & 80 & 1375 & 42 & 0.2 & 4.3 & 0.9 & 15.1 & 1.5 \\
\hline Pacific Gas \& Electric & $\mathrm{CA}$ & $\mathrm{Y}$ & 81853 & 14314 & 7878 & 547 & 1610 & 669 & 909 & 142 & 0.7 & 2.0 & 4.7 & 6.4 & 1.8 \\
\hline Puget Sound Power \& Light & WA & $\mathrm{Y}$ & 21198 & 4411 & 1113 & 260 & 1490 & 14 & 41 & 60 & 1.2 & 7.0 & 0.3 & 0.9 & 5.4 \\
\hline Wisconsin Electric Power & WI & $Y$ & 27204 & 4691 & 1348 & 345 & 1286 & 92 & 435 & 58 & 1.3 & 4.7 & 2.0 & 9.3 & 4.3 \\
\hline Texas Utilities Electric & TX & $\mathrm{Y}$ & 91537 & 18324 & 5409 & 128 & 1221 & 83 & 1314 & 20 & 0.1 & 1.3 & 0.5 & 7.2 & 0.4 \\
\hline Connec & CT & $Y$ & 27896 & 4257 & 2366 & 126 & 1160 & 22 & 267 & 41 & 0.5 & 4.2 & 0.5 & 6.3 & 1.7 \\
\hline Public & $\mathrm{CO}$ & $\mathbf{Y}$ & 23941 & 3972 & 1306 & 0 & 1071 & 0 & 251 & 9 & 0.0 & 4.5 & 0.0 & 6.3 & 0.7 \\
\hline North & MN & $\mathrm{Y}$ & 41927 & 6990 & 1859 & 271 & 1009 & 161 & 691 & 34 & 0.6 & 2.4 & 2.3 & 9.9 & 1.8 \\
\hline Florida Pov & FL & $\mathrm{Y}$ & 30669 & 6729 & 1958 & 67 & 989 & 153 & 1438 & 103 & 0.2 & 3.2 & 2.3 & 21.4 & 5.3 \\
\hline Niagara Moha & $N Y$ & Y & 40811 & 6146 & 3308 & 218 & 737 & 32 & 135 & 47 & 0.5 & 1.8 & 0.5 & 2.2 & 1.4 \\
\hline New York State Elec \& Gas & $N Y$ & $\mathrm{Y}$ & 20942 & 2517 & 1527 & 285 & 695 & 52 & 158 & 64 & 1.4 & 3.3 & 2.1 & 6.3 & 4.2 \\
\hline PacifiCorp & OR & $\mathrm{Y}$ & 61995 & 7591 & 2506 & 145 & 678 & 0 & 300 & 41 & 0.2 & 1.1 & 0.0 & 4.0 & 1.6 \\
\hline Long I & NY & $\mathrm{Y}$ & 17537 & 3967 & 2346 & 131 & 580 & 34 & 194 & 33 & 0.7 & 3.3 & 0.8 & 4.9 & 1.4 \\
\hline Massachusetts Electric & MA & $Y$ & 16192 & 2819 & 1469 & 115 & 549 & 33 & 147 & 53 & 0.7 & 3.4 & 1.2 & 5.2 & 3.6 \\
\hline Consolidated Edison & $N Y$ & $\mathbf{Y}$ & 39894 & 9059 & 5145 & 522 & 498 & 221 & 213 & 125 & 1.3 & 1.2 & 2.4 & 2.4 & 2.4 \\
\hline Arizona Public Service & $\mathrm{AZ}$ & $\mathrm{Y}$ & 21421 & 3852 & 1686 & 30 & 493 & 173 & 589 & 6 & 0.1 & 2.3 & 4.5 & 15.3 & 0.4 \\
\hline Alabama Power & AL & $\mathrm{Y}$ & 60248 & 9457 & 3008 & 35 & 449 & 38 & 802 & 22 & 0.1 & 0.7 & 0.4 & 8.5 & 0.7 \\
\hline Austin, City of & $\mathrm{TX}$ & & 7698 & 1581 & 519 & 44 & 448 & 19 & 259 & 10 & 0.6 & 5.8 & 1.2 & 16.4 & 1.9 \\
\hline Potomac Electric Power & DC & $\mathrm{Y}$ & 27642 & 5754 & 1725 & 228 & 431 & 74 & 375 & 74 & 0.8 & 1.6 & 1.3 & 6.5 & 4.3 \\
\hline Gulf Power & FL & $\mathrm{Y}$ & 11263 & 1906 & 583 & 17 & 418 & 6 & 141 & 2 & 0.1 & 3.7 & 0.3 & 7.4 & 0.3 \\
\hline Washington Water Power & WA & $\mathrm{Y}$ & 11029 & 1521 & 464 & 153 & 391 & 54 & 103 & 25 & 1.4 & 3.5 & 3.6 & 6.8 & 5.4 \\
\hline Totals top 25 & & & 1097733 & 200245 & 70241 & 5483 & 32459 & 2547 & 18899 & 1502 & 0.5 & 3.0 & 1.3 & 9.4 & 2.1 \\
\hline Top 25 as \% of national total & & & 25 & 34 & 28 & 60 & 73 & 34 & 48 & 53 & & & & & \\
\hline
\end{tabular}


because incremental amounts represent the programs' savings if they operated for a full year, but annual amounts show actual savings. These utilities must have recently expanded their DSM programs.

The utilities in California, Colorado, Connecticut, Florida, Maine, Massachusetts, Minnesota, Montana, New York, Oregon, Rhode Island, Tennessee, Washington, and Wisconsin all saved more than $2 \%$ of their retail sales in 1993 (Fig. 10). Nine of these fourteen states (Connecticut, Florida, Maine, Massachusetts, Montana, Rhode Island, Tennessee, Washington, and Wisconsin) saved more than $2 \%$ in 1992 also. Fifteen other states saved between 1 and $2 \%$ of their retail sales in 1993. Comparison of the maps in Figs. 6 and 10 shows some similarity. Utilities in the central U.S. have the least amount of DSM, based either on expenditures or savings.

Aggregate annual electricity savings exceeded 2,000 GWh in five states, California, Florida, New York, Texas, and Washington. Aggregate incremental savings exceeded $400 \mathrm{GWh}$ in California, Michigan, New York, Washington, and Wisconsin.

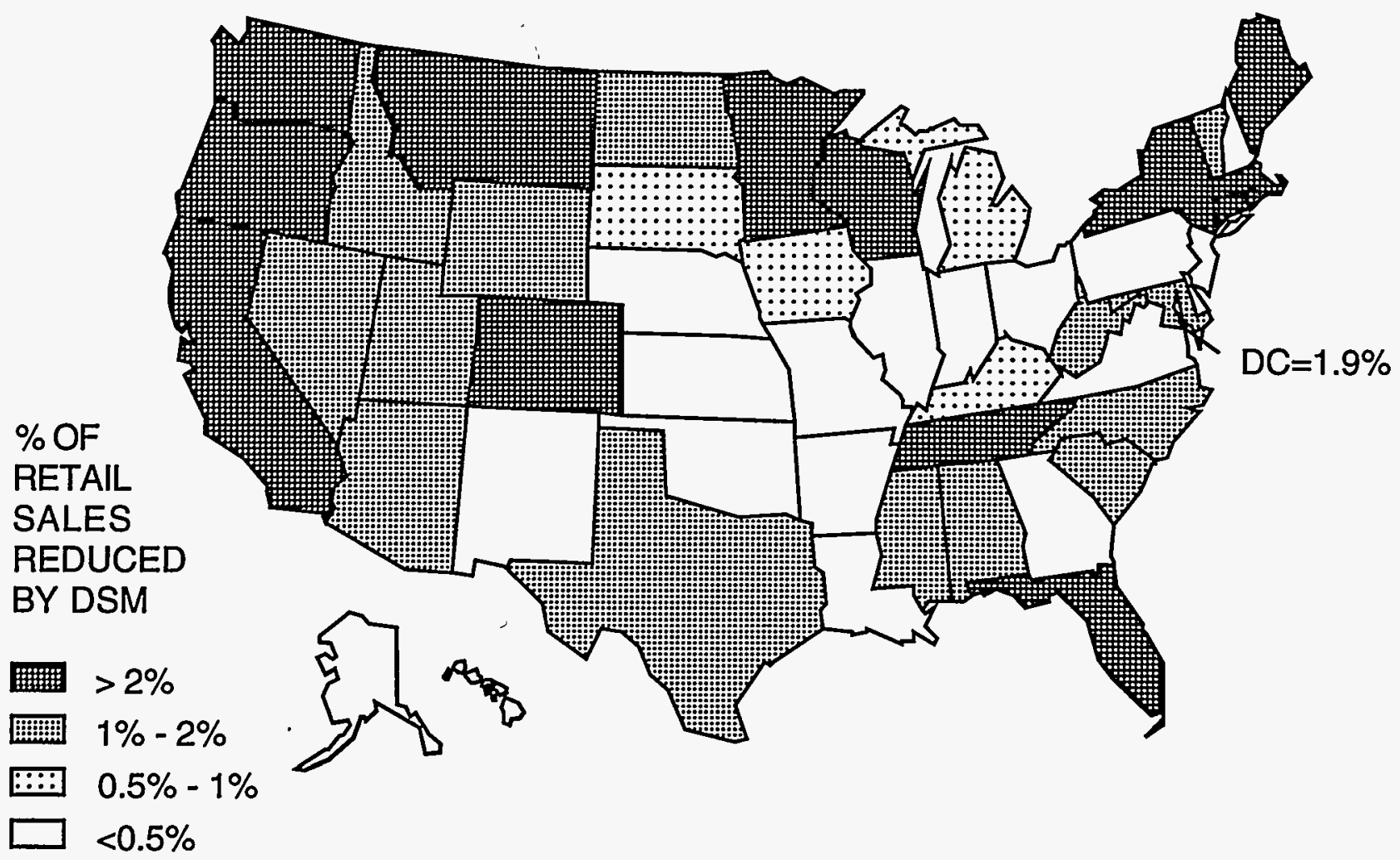

Fig. 10. Percentage reduction in retail sales caused by utility DSM programs by-state for 1993. 


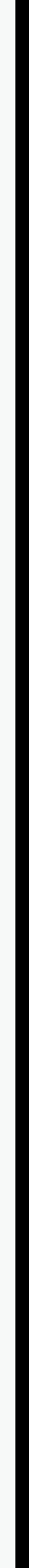




\section{DSM-PROGRAM DEMAND REDUCTIONS}

Utility DSM programs provided capacity equivalent to $39,600 \mathrm{MW}$ in 1993. Interruptible-rate programs accounted for $46 \%$ of this capacity, with energy-efficiency and direct-load-control programs each accounting for about one-fourth (Fig. 3). The incremental demand reductions totaled 7,500 $\mathrm{MW}$, one-fifth of the annual total. Interruptible programs accounted for almost half of the total incremental demand reduction. Some DSM programs, such as interruptible rates and direct load control, are dispatchable (i.e., the utility can call on that capacity much as it would turn on a combustion turbine). Other programs, such as energy efficiency, are not dispatchable (i.e., they provide capacity regardless of system need).

There is a much larger percentage reduction in peak demand (6.8\% in 1993) than in energy savings (1.6\% in 1993). Percentage peak reductions are apparently easier to achieve than energy reductions because, despite a lower proportion of overall spending (30\% versus $70 \%$ as shown in Fig. 3), percentage demand reductions are higher. Reducing peak demands often provide direct economic benefits to a utility by avoiding the need to use high-cost generation or to build new plants. And, load-management programs do not have as much effect on overall energy sales and therefore on utility revenues as do energy-efficiency programs.

The industrial sector dominates DSM-induced demand reductions. Although national data on the contributions to peak demand by sector are not available, Fig. 11 suggests that the industrial sector's peak-demand reductions (46\% incremental and 35\% annual) substantially exceed its contribution to peak demand (which is probably less than $30 \%$ of the total). In recent years, utilities have focused more of their demand-reduction efforts on the industrial sector, as shown by differences between incremental and annual demand reductions. However, there was a slight reversal in this trend with the industrial sector having a smaller share of the incremental savings in 1993 than in 1992.

Calculating the cost of reduced demand is complicated because some of the costs (in particular for interruptible-rate programs) are recurring and provide savings only for the year in question. Other costs (in particular for direct-load-control programs) are for capital (e.g., switches, controls, and communications equipment) that provide load reductions for several years. If we apply the cost of interruptible load programs ( $\$ 254$ million) to the total potential peak reduction from those programs $(18.2 \mathrm{GW})$, the resulting cost is only $\$ 14 / \mathrm{kW}$-year. If we apply the cost to only the actual peak reduction (because payments may only be required if demand is actually reduced) we get $\$ 38 / \mathrm{kW}$-year, which is still competitive with supply options.

We do not know if utilities included all of their costs in their reported expenditures. Also, some utilities may be reluctant to use their interruptible loads except in emergencies, or the 
contract terms may be such that customers simply pay higher prices rather than shed load. This means that the potential load reduction may be less than stated. But if the data are accurate, interruptible load is a cost-effective source of capacity. The cost of direct-load-control programs (using the same $5 \%$ discount rate and 10-year lifetime assumptions used for energy efficiency in Chapter 3) is $\$ 39 / \mathrm{kW}$-year.

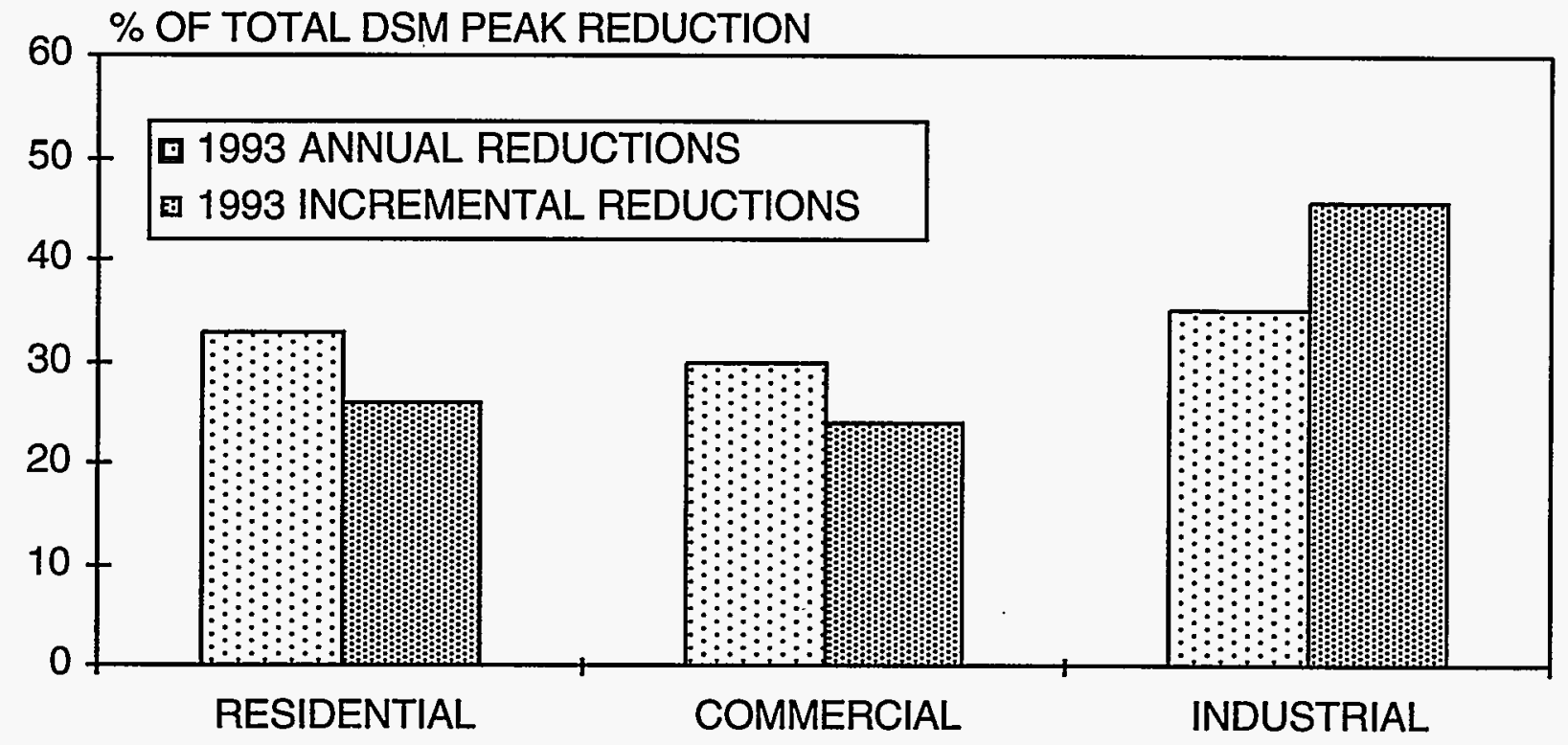

Fig. 11. Shares of 1993 annual peak reductions (effects of all DSM programs) and incremental peak savings (effects of 1993 programs) by customer class.

The distribution of utilities by percentage reduction in peak demand is much broader than the distributions of DSM costs and energy savings (compare Figs. 4 and 9 with Fig. 12). The percentage of utilities reducing demand less than $0.5 \%$ jumped from $25 \%$ to $30 \%$ in 1993 . This reflects the increase in the number of utilities with small programs, rather than a decline in the number of larger programs.

Table 6 lists the 25 utilities that reported the largest annual potential peak-demand reduction for 1993. Eighteen of these utilities were among the top 25 for 1992. The additions for 1993 include Arkansas Electric Coop., Central Power \& Light, Georgia Power, Iowa Electric Light \& Power, Mississippi County Electric Coop., Ohio Edison, and Public Service Electric \& Gas. These utilities, 22 of which are IOUs, accounted for $60 \%$ of the total U.S. annual demand reduction. These 25 utilities also accounted for $52 \%$ of the annual energy savings and $41 \%$ of the utility DSM expenditures for 1993 . Overall, these utilities cut peak demand by $11.2 \%$, almost $65 \%$ more than the national average.

Fourteen of the top 25 utilities in terms of annual demand reductions for 1993 were also among the top 25 in terms of incremental demand reductions. The 11 utilities that ranked among 
the top 25 in incremental, but not annual, demand reductions include Appalachian Power, Consolidated Edison, Consumers Power, Indiana Michigan Power, Midwest Power Systems, Minnesota Power \& Light, Ohio Power, Pennsylvania Power \& Light, Public Service Co of Oklahoma, Southern California Edison, and Southwestern Public Service.

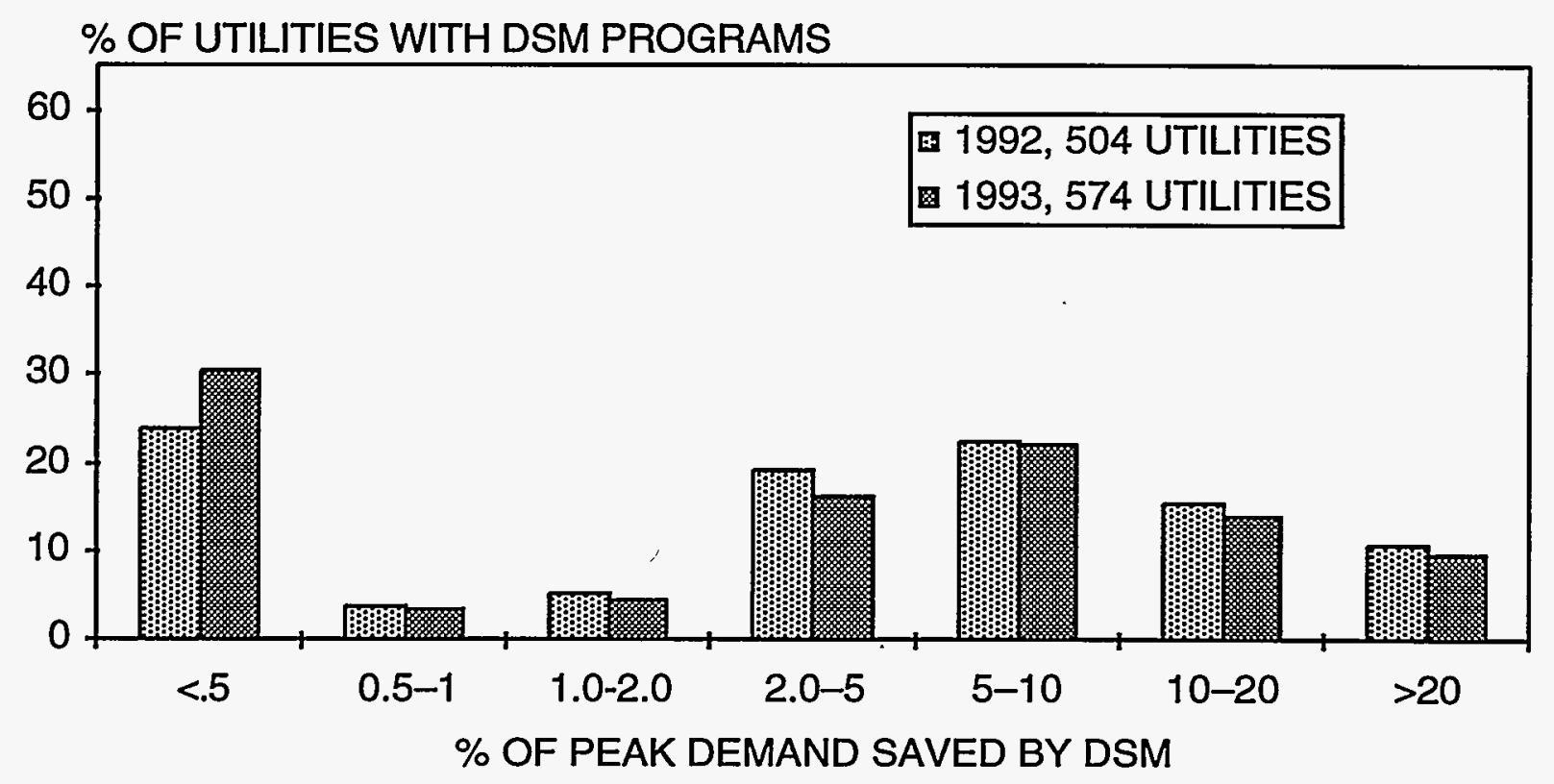

Fig. 12. Distribution of the utilities with sales over $120 \mathrm{GWh}$ that have DSM programs by percentage of potential peak demand saved.

State peak demands are not readily obtainable, because of a combination of multi-state utilities, wholesale versus retail sales, and non-coincidence of peaks among utilities. To approximate the values, we first calculated the load factor for each of the nine NERC regions. We then divided each state's energy sales values from EEI for 1993 by the load factor most applicable to each state to get an initial state peak demand. These were all adjusted so that the total peak matched the national peak demand from NERC.

Fig. 13 shows the distribution of demand reductions by state. The utilities in eight states-Alabama, Arkansas, Florida, Mississippi, North Carolina, North Dakota, Tennessee, and Vermont-reported demand reductions of $10 \%$ or more. The maps of states based on energy savings and peak demand savings (Figs. 10 and 13) have major differences. While the utilities in the Pacific Northwest spend substantial fractions of their revenues on DSM, their programs focus on energy savings, not on demand reductions, surely a consequence of the large hydroelectric resource in that region. On the other hand, utilities in the Southeast and middle of the country focus much more on peak reductions. The Southeast may have large percentage peak demand reductions because it had higher demand growth during the past decade than did other regions. 
Table 6. The 25 utilities with the largest 1993 annual demand savings caused by DSM

\begin{tabular}{|c|c|c|c|c|c|c|c|c|c|c|c|c|c|c|c|}
\hline \multirow{3}{*}{ Utility } & \multirow{3}{*}{ State } & \multirow{3}{*}{ IOU } & \multirow{3}{*}{$\begin{array}{c}\text { Output } \\
\text { (GWh) }\end{array}$} & \multirow{3}{*}{$\begin{array}{l}\text { Peak } \\
(\mathrm{MW})\end{array}$} & \multirow{3}{*}{$\begin{array}{r}\text { Revenue } \\
(\mathrm{M} \$)\end{array}$} & \multicolumn{5}{|c|}{ Total DSM programs without load building } & \multicolumn{5}{|c|}{$1993 \mathrm{DSM}$ as \% of } \\
\hline & & & & & & \multicolumn{2}{|c|}{$\Delta$ Sales (GWh) } & \multicolumn{2}{|c|}{$\Delta$ Peak $(M W)$} & \multirow{2}{*}{$\begin{array}{l}\text { Cost } \\
(M \$)\end{array}$} & \multirow{2}{*}{\multicolumn{2}{|c|}{$\frac{\text { Sales }}{\text { Incr'l Ann'l }}$}} & \multirow{2}{*}{\multicolumn{2}{|c|}{$\frac{\text { Peak }}{\text { Incr'l Ann'l }}$}} & \multirow{2}{*}{$\begin{array}{l}\text { Rev- } \\
\text { enue }\end{array}$} \\
\hline & & & & & & Incr'l & Ann'l & Incr'l & Ann'l & & & & & & \\
\hline Tennessee Valley Authority & $\mathrm{TN}$ & & 128729 & 23878 & 5349 & 26 & 3266 & 14 & 4235 & 56 & 0.0 & 2.5 & 0.1 & 17.7 & 1.1 \\
\hline Southern California Edison & $\mathrm{CA}$ & Y & 81328 & 16475 & 7387 & 970 & 6113 & 355 & 3020 & 128 & 1.2 & 7.5 & 2.2 & 18.3 & 1.7 \\
\hline Duke Power & $\mathrm{NC}$ & $\mathrm{Y}$ & 80672 & 15049 & 4282 & 39 & 74 & 204 & 1521 & 86. & 0.0 & 0.1 & 1.4 & 10.1 & 2.0 \\
\hline Florida Power & FL & $Y$ & 30669 & 6729 & 1958 & 67 & 989 & 153 & 1438 & 103 & 0.2 & 3.2 & 2.3 & 21.4 & 5.3 \\
\hline Carolina Power \& Light & NC & $\mathrm{Y}$ & 47476 & 9107 & 2895 & 78 & 2062 & 80 & 1375 & 42 & 0.2 & 4.3 & 0.9 & 15.1 & 1.5 \\
\hline Florida Power \& Light & FL & $Y$ & 78179 & 15266 & 5224 & 166 & 2738 & 169 & 1331 & 139 & 0.2 & 3.5 & 1.1 & 8.7 & 2.7 \\
\hline Texas Utilities Electric & $\mathrm{TX}$ & $\mathrm{Y}$ & 91537 & 18324 & 5409 & 128 & 1221 & 83 & 1314 & 20 & 0.1 & 1.3 & 0.5 & 7.2 & 0.4 \\
\hline Houston Lighting \& Power & $\mathrm{TX}$ & $\mathrm{Y}$ & 64053 & 11397 & 4080 & 76 & 130 & 280 & 1176 & 18 & 0.1 & 0.2 & 2.5 & 10.3 & 0.4 \\
\hline Pacific Gas \& Electric & $\mathrm{CA}$ & $\mathrm{Y}$ & 81853 & 14314 & 7878 & 547 & 1610 & 669 & 909 & 142 & 0.7 & 2.0 & 4.7 & 6.4 & 1.8 \\
\hline Alabama Power & $\mathrm{AL}$ & $\mathbf{Y}$ & 60248 & 9457 & 3008 & 35 . & 449 & 38 & 802 & 22 & 0.1 & 0.7 & 0.4 & 8.5 & 0.7 \\
\hline Northern States Power & $\mathrm{MN}$ & $\mathrm{Y}$ & 41927 & 6990 & 1859 & 271 & 1009 & 161 & 691 & 34 & 0.6 & 2.4 & 2.3 & 9.9 & 1.8 \\
\hline Tampa Electric & FL & $\mathrm{Y}$ & 16622 & 2984 & 1041 & 12 & 162 & 33 & 670 & 16 & 0.1 & 1.0 & 1.1 & 22.5 & 1.5 \\
\hline Arizona Public Service & $\mathrm{AZ}$ & $\mathrm{Y}$ & 21421 & 3852 & 1686 & 30 & 493 & 173 & 589 & 6 & 0.1 & 2.3 & 4.5 & 15.3 & 0.4 \\
\hline Baltimore Gas \& Electric & $\mathrm{MD}$ & $\mathbf{Y}$ & 32550 & 5876 & 2115 & 105 & 190 & 187 & 523 & 66 & 0.3 & 0.6 & 3.2 & 8.9 & 3.1 \\
\hline Arkansas Electric Coop & $\mathrm{AR}$ & & 7409 & 1630 & 286 & 0 & 0 & 75 & 444 & 0 & 0.0 & 0.0 & 4.6 & 27.2 & 0.0 \\
\hline Oklahoma Gas \& Electric & OK & $\mathrm{Y}$ & 24958 & 5010 & 1283 & 8 & 124 & 17 & 439 & 19 & 0.0 & 0.5 & 0.3 & 8.8 & 1.5 \\
\hline Wisconsin Electric Power & WI & $\mathrm{Y}$ & 27204 & 4691 & 1348 & 345 & 1286 & 92 & 435 & 58 & 1.3 & 4.7 & 2.0 & 9.3 & 4.3 \\
\hline Ohio Edison & $\mathrm{OH}$ & $\mathrm{Y}$ & 30108 & 5068 & 2103 & 17 & 61 & 5 & 396 & 15 & 0.1 & 0.2 & 0.1 & 7.8 & 0.7 \\
\hline Georgia Power & GA & $\mathrm{Y}$ & 79531 & 12573 & 4451 & 52 & 134 & 109 & 380 & 52 & 0.1 & 0.2 & 0.9 & 3.0 & 1.2 \\
\hline Potomac Electric Power & $\mathrm{DC}$ & $\mathrm{Y}$ & 27642 & 5754 & 1725 & 228 & 431 & 74 & 375 & 74 & 0.8 & 1.6 & 1.3 & 6.5 & 4.3 \\
\hline Philadelphia Electric & $\mathrm{PA}$ & $\mathrm{Y}$ & 44717 & 7100 & 3575 & 8 & 60 & 42 & 370 & 11 & 0.0 & 0.1 & 0.6 & 5.2 & 0.3 \\
\hline Public Service Electric\&Gas & NJ & $Y$ & 43221 & 6145 & 3693 & 57 & 57 & 204 & 368 & 50 & 0.1 & 0.1 & 3.3 & 6.0 & 1.4 \\
\hline Iowa Electric Light \& Power & IA & $\mathrm{Y}$ & 11598 & 1716 & 551 & 24 & 21 & 150 & 339 & 5 & 0.2 & 0.2 & 8.7 & 19.7 & 1.0 \\
\hline Central Power \& Light & $\mathrm{TX}$ & $\mathbf{Y}$ & 19122 & 3518 & 1224 & 20 & 185 & 8 & 336 & 7 & 0.1 & 1.0 & 0.2 & 9.6 & 0.5 \\
\hline Mississippi Cnty Elec Coop & $\mathrm{AR}$ & & 1761 & 321 & 54 & 0 & 0 & 58 & 311 & 0 & 0.0 & 0.0 & 18.2 & 97.0 & 0.1 \\
\hline Totals top 25 & & & 1174537 & 213223 & 74464 & 3309 & 22864 & 3433 & 23785 & 1171 & 0.3 & 1.9 & 1.6 & 11.2 & 1.6 \\
\hline Top 25 as $\%$ of national totals & & & 27 & 37 & 30 & 36 & 52 & 46 & 60 & 41 & & & & & \\
\hline
\end{tabular}


Aggregate annual demand reductions exceeded 1,000 MW in eight states, including Alabama, California, Florida, North Carolina, Pennsylvania, South Carolina, Tennessee, and Texas. Incremental load reductions exceeded $400 \mathrm{MW}$ in four states-California, Florida, New York, and Texas.

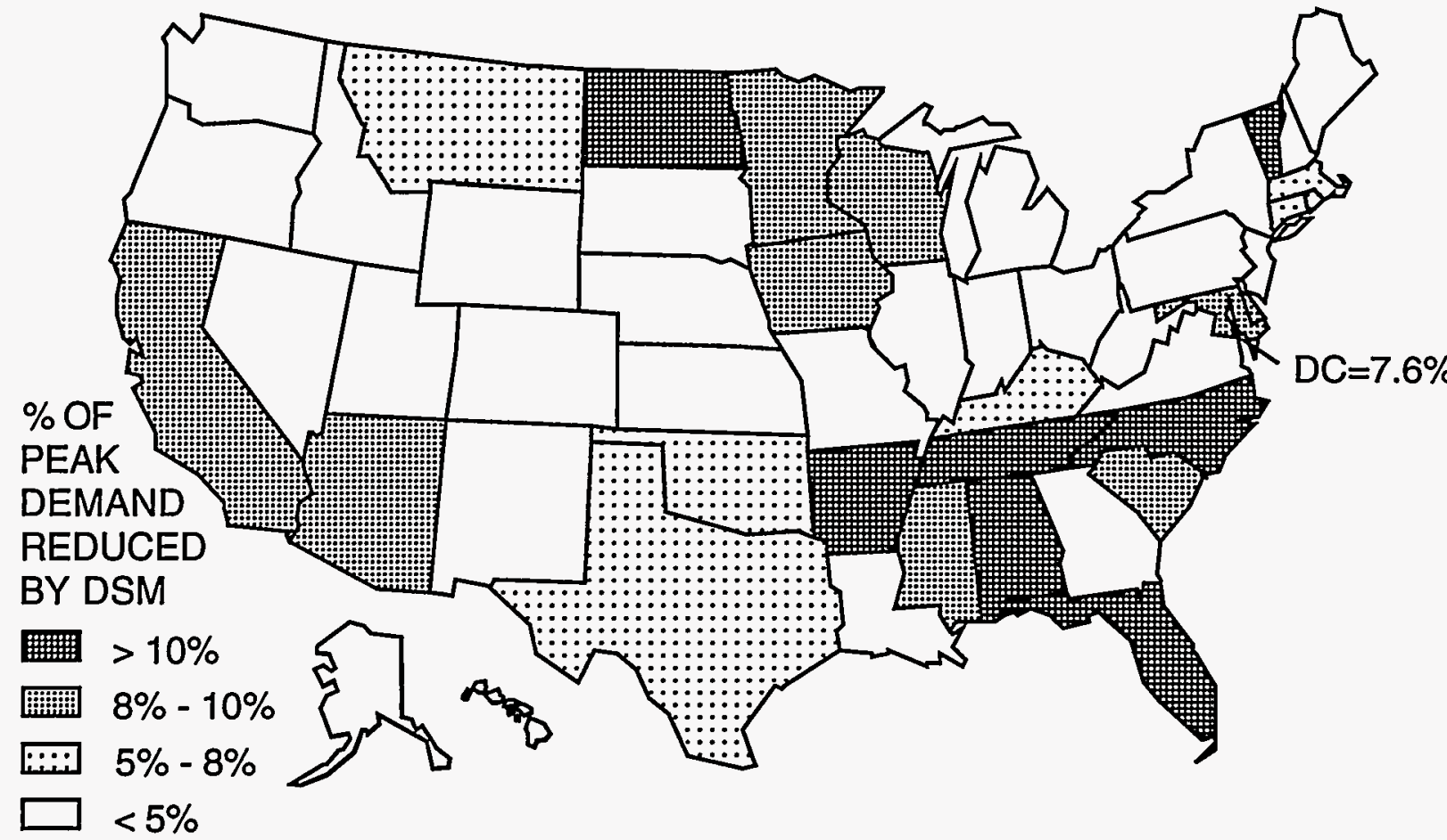

Fig. 13. Percentage reduction in potential peak demand caused by utility DSM programs by state for 1993. 


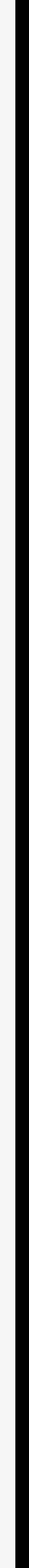




\section{UTILITY TRENDS AND FORECASTS TO 1998}

EIA asked utilities to estimate DSM-program costs and effects for 1994 and 1998. The utilities prepared projections in Spring 1994. Here we examine these projections as well as those from the year before. These projections are normalized using data and forecasts from EIA (1994b and c), EEI (1994), and NERC (1994).

\section{NATIONAL FORECASTS}

Utilities project their expenditures on DSM programs to increase from $1.46 \%$ of retail revenues in 1993 to $1.52 \%$ in 1994 and 1.51\% in 1998 (Fig. 3 and Table 2). In real dollars, this equals a $2.5 \%$ annual growth rate. This represents a significant flattening of the expected spending on future DSM. Actual expenditures for 1993 were $6.5 \%$ below what was projected in Spring 1993. The current growth projection is only a third of last year's projected $8 \%$ annual rate between 1993 and 1997. Extrapolating last year's 1997 data to 1998 shows that current projections for spending in 1998 are $20 \%$ below the earlier projection.

These lowered projections can be interpreted as either a maturing of the DSM industry or the beginning of a slackening in utility commitment to DSM. They do not yet show a reduction in DSM-program size, and for every utility that is reducing its programs, others show continued growth. These data are based on utility expectations as of Spring 1994, before the California Public Utility Commission's "Blue Book" proposal on direct access increased speculation on the future structure of the electricity industry. Since then, many utilities have reported plans to reduce the size and cost of their DSM programs. Next year's EIA-861 data will show better the impact of electric-industry restructuring on DSM. On the other hand, because our data set includes only utilities that now operate DSM programs, it does not include utilities that will start programs in the future. To that extent, it may undercount the future of DSM.

Forecast reductions in annual energy use increase from $1.6 \%$ in 1993 to $3.0 \%$ in 1998 , and potential demand reductions grow from $6.8 \%$ to $8.9 \%$. These both show continued strong increases, as the accumulated impacts of each year's programs add up. Compared to last year's forecast for 1993 and 1997, energy savings expectations are unchanged and peak reductions are $4 \%$ higher than previously projected (after extrapolating to 1998). The actual 1993 peak reduction is $9 \%$ higher than what was projected in 1992. Because the same utilities are expecting lower expenditures than previously, they must be expecting greater cost-effectiveness from their DSM programs. 


\section{REGIONAL FORECASTS}

National averages hide a great deal of variation across geographic regions. Each utility belongs to one of the nine NERC regions (Fig. 14). In earlier chapters, we showed state-by-state differences for 1993. NERC regions provide a natural grouping of utilities to show the broader regional impacts of DSM programs. Using NERC regions avoids the errors involved in allocating DSM parameters of a single utility to multiple jurisdictions. Also, NERC publishes peak demands and projected revenues for each region.

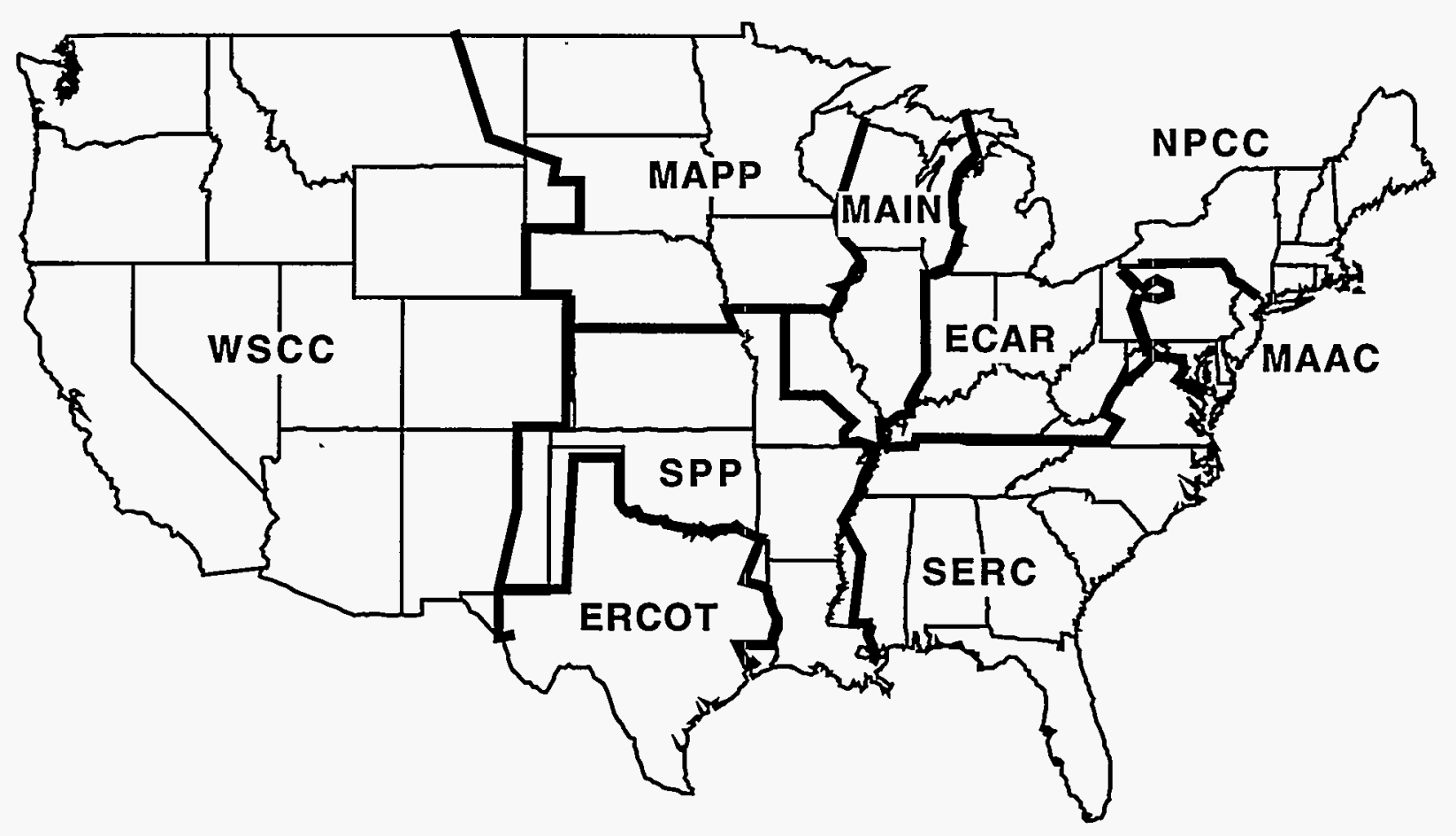

Fig. 14. North American Electric Reliability Council regions for the contiguous U.S.

DSM-expenditure trends differ across regions (Fig. 15). Although the Northeast has been the leader in percentage of revenues spent on DSM, its percentage has declined since 1992 and is projected to decline further over the coming years. The West is projected to surpass the Northeast in 1994. The Mid-America region shows an increase in 1998 despite decreases from 1992 through 1994. Overall, eight of the nine regions show growth in the percentage of spending on DSM between 1993 and 1998.

The DSM-induced reduction in annual electricity sales are again greatest in the Northeast and West, and expected to reach around 6\% in 1998 (Fig. 16). On the other hand, DSM programs are expected to cut electricity use by less than $0.5 \%$ in the Southwest.

Finally, Fig. 17 shows the effects of DSM programs on reducing peak demands in each NERC region. On this measure, the Mid-Continent and Southeast regions lead, with planned 
reductions of more than $12 \%$ by 1998 or sooner. The East Central region is the only one with a projected reduction in peak demand of less than $5 \%$.

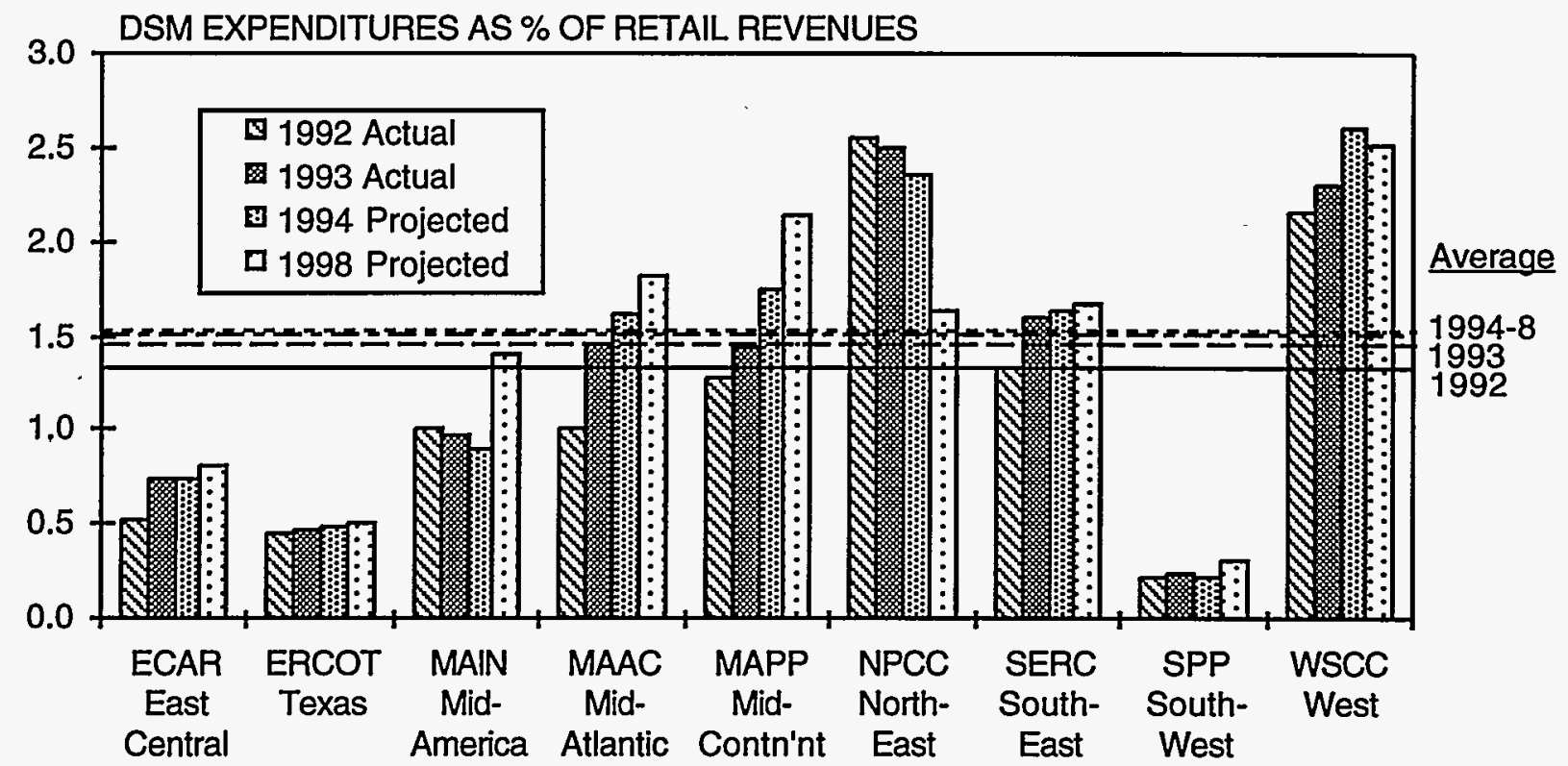

Fig. 15. DSM expenditures as a percentage of retail revenue for each NERC region for 1992, 1993, and projected 1994 and 1998.

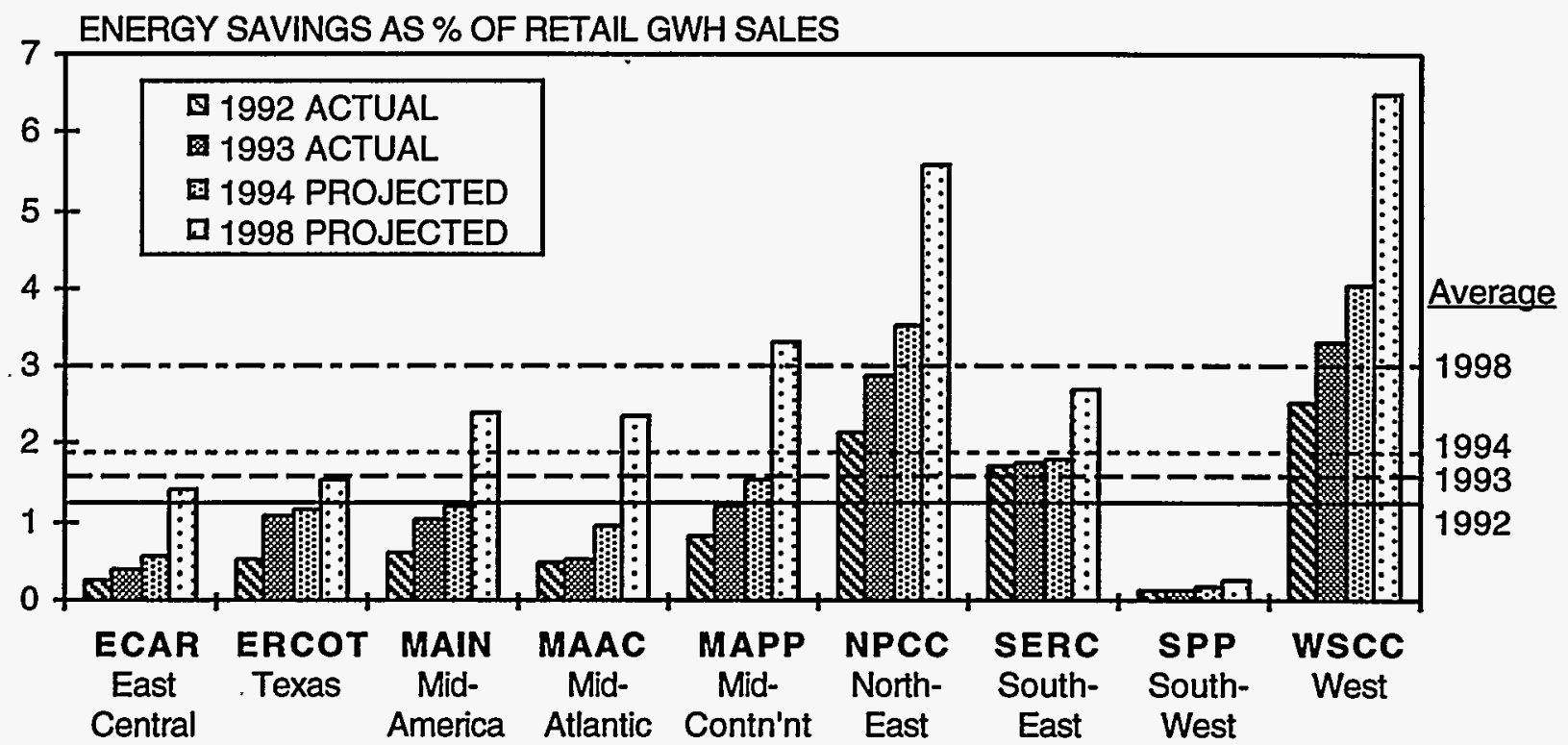

Fig. 16. Energy savings as a percentage of total sales for each NERC region for 1992, 1993, and projected 1994 and 1998. 


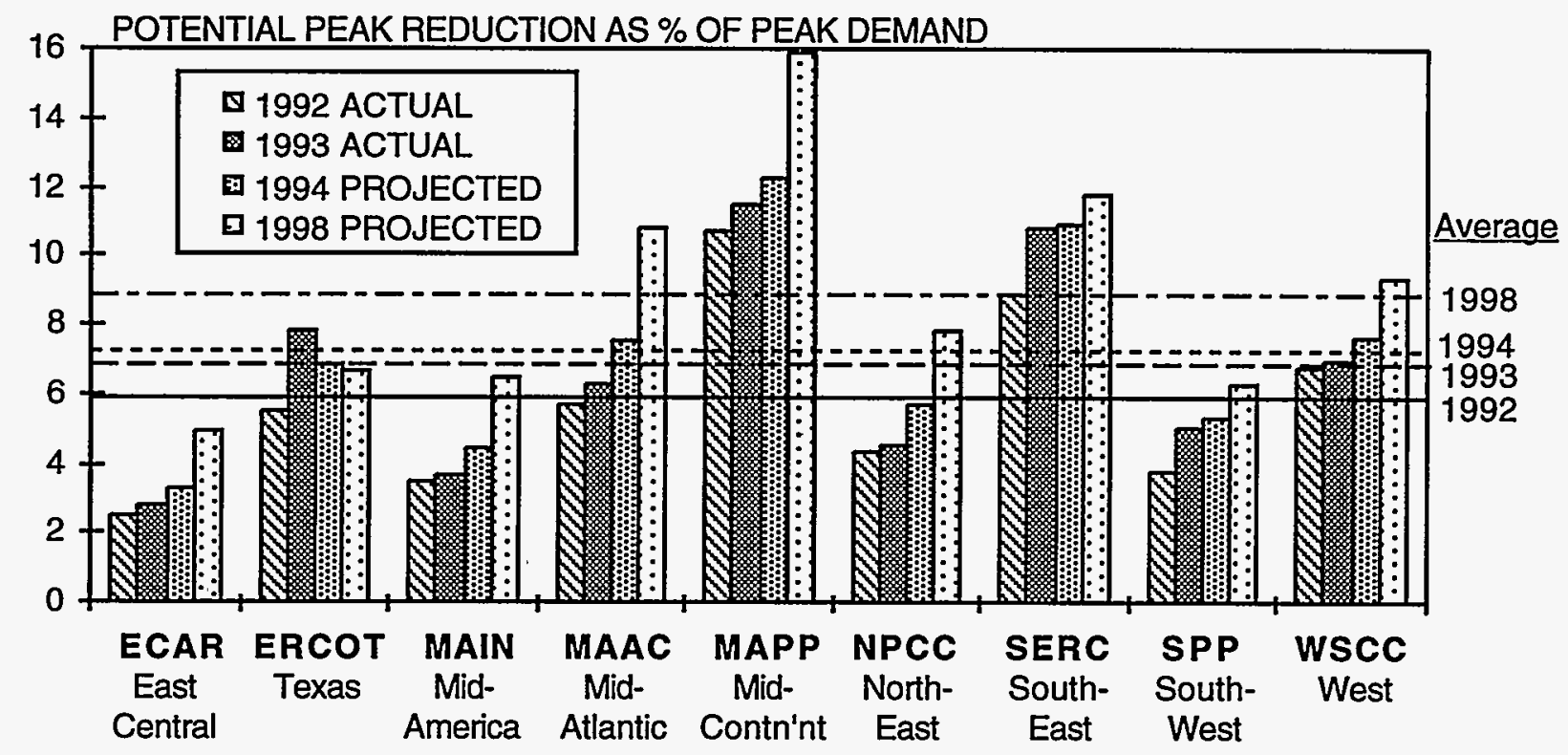

Fig. 17. Potential peak demand reduction as a percentage of total peak for each NERC region for 1992, 1993, and projected 1994 and 1998. 
Now with five years of data (1989-1993), the EIA-861 database provides a comprehensive time-series, cross-sectional view of U.S. utility DSM activities. Although it is unlikely that the data are totally consistent and accurate across all utilities, the level of detail and near- $100 \%$ coverage of the industry makes EIA- 861 a rich source of information.

The 1989-1993 results and 1998 projections lead to several findings, many of which are continuations or slight variations of previous years' findings. They are:

- The expenditures and effects of utility DSM programs have grown steadily each year from 1989 through 1993. In 1993, utilities spent 1.5\% of electric revenues on DSM and cut electricity sales and peak demands by 1.6 and $6.8 \%$, respectively.

- As was true in prior years, investor-owned utilities devoted larger fractions of their revenues to DSM than did consumer-owned utilities. They also surpassed COUs in energy reductions, but not in peak-demand savings. Projections show COUs surpassing IOUs in 1994 in all three categories.

- $\quad$ Energy-efficiency programs dominated DSM expenditures and energy savings, accounting for $70 \%$ of total utility DSM costs and $90 \%$ of energy savings but only $26 \%$ of peakdemand reductions. Interruptible-rate programs were the most important in cutting peak demands, accounting for almost half of the 1993 annual demand reduction.

- The residential sector accounted for a disproportionate share of DSM-induced electricity savings, with the industrial sector getting-much less attention. However, the industrial sector dominated demand reductions, accounting for almost half the total reduction. Utility attention has shifted from the residential and industrial sectors to the commercial sector for energy savings and from the residential sector to the industrial sector for demand reductions.

- $\quad$ Although DSM activity is concentrated among a few utilities, this concentration is less than it was in previous years. Whereas only $24 \%$ of the 439 DSM utilities with sales greater than $120 \mathrm{GWh}$ in 1991 spent more than 1\% of revenues on DSM, $28 \%$ of the 504 utilities in 1992 and $29 \%$ of the 574 utilities in 1993 spent more than $1 \%$. Thirteen percent of the utilities reported energy savings of more than $2 \%$ in 1993 , compared with only $10 \%$ in 1992. 
- $\quad$ Although DSM expenditures are still greatest in the Northwest and Northeast, spending increased most significantly in the Rocky Mountain, mid-Atlantic, and Southeast states, with other states also showing growth.

- On average, the utilities delivered energy savings from energy-efficiency programs at a cost of $3.0 \notin / \mathrm{kWh}$ and demand reductions from direct load-control programs at a cost of $\$ 39 / \mathrm{kW}$-year. Interruptible-load programs provided very low-cost capacity between $\$ 14$ and $\$ 38 / \mathrm{kW}$-year. These utility costs are often lower than the costs of providing new baseload energy or peaking capacity, respectively. These values, however, are based on simplifying assumptions and gross totals for utilities. Actual costs can differ greatly.

- Utility DSM expenditures in 1993 were 7\% below the levels estimated in early 1993 on the 1992 EIA-861 submissions. Interestingly, the 1993 energy savings were about the same as that estimated on the 1992 forms and the 1993 demand reductions were $9 \%$ higher than that estimated on the 1992 forms.

- Utility projections show slow growth in DSM expenditures between 1993 and 1998. Annual utility DSM expenditures are expected to increase 29\% during this period, a $2.5 \%$ per year growth in real dollars. This growth is one-third of last year's projected $8 \%$ rate. Spending in 1998 is currently projected to be $20 \%$ below extrapolations of last year's projection. All NERC regions show projected growth except the Northeast, but its decline offsets the growth in the other regions.

- Energy savings are expected to grow as new programs add to the savings of current programs. Projections show a doubling in savings between 1993 and 1998. Potential demand reductions are expected to increase $40 \%$. These projections show that future DSM programs are expected to concentrate more on energy efficiency than on demand reductions.

- We anticipate that the actual 1994 spending and effects will fall below the projections discussed here (prepared in Spring 1994). We also expect DSM spending for later years to fall below the Spring 1994 forecasts for 1998. Recent reports from utilities in some states show cuts in DSM spending.

These EIA-861 data show a slowdown in the growth of DSM expenditures from previous years but do not show a decline. Projected savings show the same or higher growth as before, so it is difficult to say whether utilities are expecting greater cost-effectiveness or have not yet adjusted their savings projections to match their expenditure projections. Utilities prepared their estimates in Spring 1994. Much has happened since then that could change utility DSM plans. Increased competition could drive utilities to concentrate on lower prices rather than on lowering the overall cost of electricity services. This would lessen the attractiveness of DSM to utilities because of its impact on rates (Hirst and Hadley 1994). An even broader restructuring could deintegrate the industry and make it unclear who has responsibility for DSM. State regulatory commissions have a substantial influence on the nature and extent of utility DSM programs 
(Schweitzer and Young 1994). If competition erodes the retail monopoly franchise, regulators may not be able to impose DSM requirements on utilities.

Recent trade newsletters show a mix of utility DSM programs increasing and decreasing. Some articles describe new DSM programs that have been started, increases in budgets, or high expectations of future savings (e.g., Virginia Power, Idaho Power, Texas Utilities, New York Power Authority). Others describe utility cuts in current or future DSM budgets (e.g., Pacific Gas \& Electric, Consumers Power, Consolidated Edison). Although the anecdotal evidence is not conclusive, it appears that the announced cutsexceed the planned growth. But the overall picture depends on the increases or decreases at utilities that do not necessarily make the newsletters. Work sponsored by the U.S. Department of Energy is underway at ORNL and other organizations to find out why utilities are cutting back and what pressures are most critical in influencing their decisions.

Several utilities and public service commissions have shifted their criteria for acceptable DSM programs from the Total Resource Cost (TRC) test to the Rate Impact Measure (RIM) test. For example, the Florida public service commisșion approved use of the RIM test as the sole method for setting DSM goals. Detroit Edison has requested changes in its DSM program to implement only those options that pass the RIM test or add value to customer services. However, other commissions continue to emphasize the TRC test. Examples include Oregon and New. Jersey. The TRC test judges the worthiness of a DSM program based on the overall cost for the energy service, while the RIM test is based on the DSM program's effect on electricity prices to non-participants. Programs that pass the RIM test generally place more of the cost burden of DSM on the participant. To the extent that customer cost limits participation, then programs will have lower participation, and fewer DSM programs will be judged cost effective. If more utilities utilize the RIM test because of worries about competition, utilities may reduce their DSM programs.

Over the coming years, the electric industry may change greatly. How quickly and into what form is unclear. The long-term survival of DSM in a transformed market will depend on a number of factors: the continued belief by utilities that DSM is a valuable customer service, the ability of regulators to shape the new market so that societally cost-effective programs are maintained, and the creativity of DSM practitioners to modify DSM programs to take advantage of the new market structure. The future of DSM is daily being created and cannot be confidently predicted in these chaotic times.

\section{ACKNOWLEDGEMENTS}

We thank Ralph Cavanagh, Ahmad Faruqui, Ted Flanigan, Peter Miller, Barry Moline, Rick Morgan, Diane Pirkey, Larry Prete, Deborah Ross, Frank Schultz, Marty Schweitzer, Tom Stanton, and Ed Vine for their helpful comments on a draft of this report. 



\section{REFERENCES}

Edison Electric Institute 1993, Statistical Yearbook of the Electric Utility Industry 1992, No. 60, Washington, DC, October.

Edison Electric Institute 1994, Advance Release of Data: 1993 Statistical Yearbook of the Electric Utility Industry, Washington, DC, May.

Energy Information Administration 1994a, Electric Power Annual 1993, DOE/EIA-0348(93), U.S. Department of Energy, Washington, DC, December.

Energy Information Administration 1994b, Annual Energy Outlook 1994 with Projections to 2010, DOE/EIA-0383(94), U.S. Department of Energy, Washington, DC, January.

Energy Information Administration 1994c, Supplement to the Annual Energy Outlook 1994, DOE/EIA-0554(94), U.S. Department of Energy, Washington, DC, March.

J. Eto, E. Vine, L. Shown, R. Sonnenblick, and C. Payne 1994, The Cost and Performance of Utility Commercial Lighting Programs, LBL-34967, Lawrence Berkeley Laboratory, Berkeley, CA, May.

T. Flanigan and S. Hadley 1994, Analysis of Successful Demand-Side Management at Publicly Owned Utilities, ORNL/CON-397, Oak Ridge National Laboratory, Oak Ridge, TN, August.

E. Hirst 1992, Electric-Utility DSM Programs: 1990 Data and Forecasts to 2000, ORNL/CON347, Oak Ridge National Laboratory, Oak Ridge, TN, June.

E. Hirst 1993, Electric-Utility DSM Program Costs and Effects: 1991 to 2001, ORNL/CON-364, Oak Ridge National Laboratory, Oak Ridge, TN, May.

E. Hirst 1994, Costs and Effects of Electric-Utility DSM Programs: 1989 to 1997, ORNL/CON392, Oak Ridge National Laboratory, Oak Ridge, TN, June.

E. Hirst and S. Hadley 1994, Price Impact of Electric-Utility DSM Programs, ORNL/CON-402, Oak Ridge National Laboratory, Oak Ridge, TN, December.

E. Hirst and C. Sabo 1991, Electric-Utility DSM Programs: Terminology and Reporting Formats, ORNL/CON-337, Oak Ridge National Laboratory, Oak Ridge, TN, October.

P. L. Joskow and D. B. Marron 1992, "What Does a Negawatt Really Cost: Evidence from Utility Conservation Programs," The Energy Journal 13(4), 41-74. 
North American Electric Reliability Council 1994, Electricity Supply \& Demand, Version 1.2, Princeton, NJ, November.

M. Schweitzer and T. R. Young 1994, State Regulation and its Effects on Electric-Utility Use of DSM Resources, ORNL/CON-391, Oak Ridge National Laboratory, Oak Ridge, TN, August. 
INTERNAL DISTRIBUTION

1. D. Bauer

2. L. Baxter

3. V. D. Baxter

4. L. Berry

5. D. S. Bjornstad

6. R. Braid

7. M. A. Brown

8. J. B. Cannon

9. F. C. Chen

10. J. Christian

11. G. Courville

12. T. R. Curlee

13. P. D. Fairchild

14. S. Hadley

15. L. J. Hill

16. E. Hillsman

17. E. Hirst

18. P. J. Hughes

19. M. A. Kuliasha
20. R. Lee

21. P. Leiby

22. J. M. MacDonald

23. V. C. Mei

24. S. Purucker

25. D. E. Reichle

26. D. T. Rizy

27. A. C. Schaffhauser

28. M. Schweitzer

29. R. B. Shelton

30. B. E. Tonn

31. J. Van Dyke

32. J. Vancoevering

33. J. M. Veigel (ORAU)

34. T. J. Wilbanks

35. ORNL Patent Office

36. Central Research Office

37. Document Reference Section

38. Laboratory Records (RC)

39-41. Laboratory Records Dept.

\section{EXTERNAL DISTRIBUTION}

42. Dr. Douglas R. Bohi, Director, Energy and Natural Resources Division, Resources for the Future, 1616 P Street, N.W., Washington, DC 20036

43. Dr. Thomas E. Drabek, Professor, Department of Sociology, University of Denver, Denver, CO 80208-0209

44. Dr. Stephen G. Hildebrand, Director, Environmental Sciences Division, Oak Ridge National Laboratory, Post Office Box 2008, Oak Ridge, TN 37831-6037

45. Calvin MacCracken, President, Calmac Manufacturing Corporation, 101 West Sheffield Avenue, P. O. Box 710, Englewood, NJ 07631

46. Jacqueline B. Shrago, Director, Office of Technology Transfer, 405 Kirkland Hall, Vanderbilt University, Nashville, TN 37240

47. Mr. George F. Sowers, P. E., Senior Vice President, Law Companies Group, Inc., 114 Townpark Drive, Suite 250, Kennesaw, GA 30144-5599

48. Dr. C. Michael Walton, Ernest H. Cockrell Centennial Chair in Engineering and Chairman, Department of Civil Engineering, University of Texas at Austin, Austin, TX 78712-1076

49.-50. OSTI, U. S. Department of Energy, P. O. Box 62, Oak Ridge, TN 37831

51. Office of Assistant Manager for Energy Research and Development, DOE/ORO, P. O. Box 2001, Oak Ridge, TN 37831-8600

52.-800. External Energy and Global Change Analysis Section distribution mailing list and extra copies to E.M. Schorn, 4500N, H-19A 